\title{
Networking as a Barrier to Entry
}

\section{and the Competitive Supply of Venture Capital * +}

\author{
Yael Hochberg \\ Kellogg School of Management \\ Northwestern University
}

\author{
Alexander Ljungqvist \\ Stern School of Business \\ New York University \\ and $C E P R$
}

\author{
Yang Lu \\ Stern School of Business \\ New York University
}

May 6, 2007

\footnotetext{
* Thanks for helpful comments and suggestions go to John Asker, Ola Bengtsson, Jan Eberly, Shane Greenstein, Arvind Krishnamurthy, Laura Lindsey, Andrew Metrick (our AFA discussant), Leslie Papke, Mitchell Petersen, David Scharfstein (our EVI discussant), Morten Sørensen, Scott Stern, Per Strömberg (our RICAFE2 discussant), Toby Stuart (our NBER discussant), Toni Whited, Jeffrey Wooldridge, and seminar participants at the European Central Bank, Cornell University, Northwestern University, the University of Texas at Austin, the City University of New York, Hong Kong University of Science and Technology, the University of Pittsburgh, the University of Wisconsin-Madison, the Australian National University, the University of Zurich, the Berkley Workshop at New York University, the 2007 American Finance Association meeting, the 2006 RICAFE2 Conference at the LSE, the Third EVI Conference at Harvard University, the 2006 NBER Entrepreneurship Meetings, and the 2007 Next Generation Conference at LBS. Lu gratefully acknowledges funding from the Ewing Marion Kauffman Foundation. † Address correspondence to: y-hochberg@kellogg.northwestern.edu (Hochberg), aljungqv@stern.nyu.edu (Ljungqvist), or ylu1@stern.nyu.edu (Lu).
} 


\title{
Networking as a Barrier to Entry
}

\section{and the Competitive Supply of Venture Capital}

\begin{abstract}
We examine whether networks among incumbent venture capital firms help restrict entry into local VC markets in the U.S., thus improving VCs' bargaining power over entrepreneurs. We show that VC markets with more extensive networking among the incumbent players experience less entry. The effect is sizeable economically and appears robust to plausible endogeneity concerns. Entry is accommodated if the entrant has established relationships with a target-market incumbent in its own home market. In turn, incumbents react strategically to an increased threat of entry, in the sense that they freeze out any incumbent that builds a relationship with a potential entrant. Finally, companies seeking venture capital raise money on worse terms in more densely networked markets while increased entry is associated with higher valuations.
\end{abstract}

Key words: Venture Capital, Start-up Financing, Networks, Syndication, Barriers to Entry, Entry Deterrence.

JEL classification: G24, L13, L14, L22, L84. 
Entrepreneurship and innovation are commonly considered key determinants of an economy's capacity for wealth creation, job growth, and competitiveness. Venture capitalists serve a vital economic function by identifying, funding, and nurturing promising entrepreneurs, though whether they provide capital and services on competitive terms is much debated. In this paper, we examine whether U.S. venture capital firms engage in practices designed to increase their bargaining power over entrepreneurs, by restricting entry into local VC markets, such as Silicon Valley in California or Route 128 in Massachusetts. Our results are consistent with the hypothesis that incumbents engage in strategic behavior that reduces entry and benefit from doing so through paying lower prices for their investments.

What does it take to enter a local VC market? There are no obvious natural or regulatory barriers to entry; VCs are free to open offices in any location they choose. But to do deals in what is, after all, a relatively opaque and above all private market, they need to be visible to local entrepreneurs who, moreover, must consider them a credible funding source worth approaching. If entrants wish to be proactive about sourcing deal flow, they need access to information about promising ideas, trends, and people, preferably ahead of other VCs. And once they have found start-ups to back, they need local knowledge and connections to provide them with "value-added services", such as help identifying managerial talent, suppliers, or customers.

Having to establish visibility, credibility, access to information, and local knowledge from scratch puts entrants at an obvious cost and time disadvantage relative to incumbents, but this ignores an additional important advantage to incumbency, namely network externalities. VCs routinely cooperate by referring deals and people to each other, helping to put funding together through investment syndicates, providing introductions to suppliers or customers, and sharing their resources in other ways. Indeed, they may sometimes do so specifically to raise the cost of 
entry. For instance, by referring promising deals they cannot fund themselves to their friends, incumbent VCs may be able to reduce the time entrepreneurs spend searching for funding, with the result that entrants are less likely to see the deal flow (Inderst and Mueller (2004)). Or they may refuse to join an entrant's syndicate, making it harder for the entrant to assemble funding for any deal that requires syndication, perhaps due to its size or risk profile.

If life as a VC is easier for those who are already members of the club, perhaps the most costeffective way to enter a VC market is to gain an incumbent's cooperation - in the form of access to the incumbent's information, expertise, or contacts - with a view to eventually gaining admission to the club. This raises two questions: What incentives does an incumbent have to cooperate with an entrant? And how will other incumbents react?

The most obvious inducement an entrant can offer in return for cooperation in the target market is access to its home market. Thus, entry may involve an element of reciprocity. That benefits the cooperating incumbent but must be balanced against any negative reaction from the other incumbents. More formally, consider a group of incumbent VCs, each of which maximizes its profit while considering the effect of its actions on the behavior of the others. Individually, each VC chooses whether or not to cooperate with an entrant trying to break into the market. If an incumbent chooses to cooperate, it expects to be punished by the other incumbents. The resulting Nash equilibrium is a function of the expected severity of punishment. The harsher is expected punishment, the more likely it is that incumbents will refrain from helping entrants. An incumbent's dominant strategy then depends on the gain from dealing with an entrant (such as reciprocal access to the entrant's home market), the expected punishment (such as refusal to cooperate with the deviating VC for one or more periods), and (because coordinating punishment becomes harder the more incumbents there are) the number of incumbents. 
While many forms of cooperation are not observable, it is possible to use data on syndication relationships to proxy for how interdependent incumbents have chosen to be. VC firms that are prone to sharing their investments with other incumbents presumably also share other network resources. ${ }^{1}$ All else equal, we expect more densely networked markets to be harder to enter, not only because of the relatively greater network externalities that incumbents (but not entrants) enjoy in such markets, but also because withdrawal of network access ("suspension from the club") may provide an effective threat of punishment against the offender. ${ }^{2}$

Our results are consistent with the hypothesis that networking among venture capitalists reduces entry. First, we find that there is less entry in VC markets in which incumbents are more tightly networked with each other, as evidenced by their past syndication patterns. The magnitude of the effect is large: Controlling for other likely determinants of market entry, a onestandard deviation increase in the extent to which incumbents are networked (using measures borrowed from economic sociology) reduces the number of entrants in the median market by around a third.

The networking patterns we observe in the data may not be exogenous; rather, they may reflect omitted variables affecting both networking and entry. For example, unobserved variation in the cost of doing business in a given industry or location could induce networking (say, to economize on information costs) and independently reduce entry. To correct for this potential endogeneity problem, we follow two approaches. First, we use instrumental variables motivated by non-strategic and mechanical determinants of syndication decisions. This strengthens our

\footnotetext{
${ }^{1}$ Reasons to syndicate include pooling capital and diversifying risk (Lerner (1994)), improved screening (Sah and Stiglitz (1986)), obtaining access to other VCs' deal flow on a reciprocal basis (Lerner (1994)), and the ability to draw on the expertise of other VCs when nurturing investments (Brander, Amit, and Antweiler (2002)).

${ }^{2}$ Anecdotal evidence supports a link between entry and networking. Kuemmerle and Ellis (1999) report that when planning its ultimately successful entry into the U.S. venture capital market, the president of Japan-based JAFCO Ltd. "suspected that the densely networked U.S. VC industry would present considerable barriers to entry."
} 
results. Second, we exploit the nested-panel structure of our data to identify omitted time-varying factors that are either location-specific or industry-specific. This produces results that are very similar to the IV estimates.

Our second test focuses on the probability that a potential entrant successfully enters a market. Strong networks among the incumbents in the target market reduce the likelihood of entry. But not every potential entrant is deterred. Controlling for geographic proximity to the target market and prior experience in the industry (which each double the likelihood of entry), we find that a potential entrant is significantly more likely to enter if it has previously established ties to incumbents through inviting them into syndicates in its own home market. Moreover, it is with these very same incumbents that the entrant does business in the target market. In the context of the entry deterrence game sketched out above, this suggests that incumbents deviate from the strategy of non-cooperation with entrants when the gain from deviating - reciprocal access to the entrant's home market - is sufficiently tempting.

The cost of deviation is punishment, in the form of reduced syndication opportunities with fellow incumbents. We show that after doing business with a potential entrant, an incumbent's probability of being invited into fellow incumbents' syndicates decreases considerably and significantly for up to five years after the event. This effect is concentrated in markets with a small number of incumbents, consistent with the notion that punishment invites free-riding and so is viable only with a small number of players.

Finally, we examine the price effect of reduced entry by comparing the valuations of companies receiving VC funding in relatively more protected and relatively more open markets. Controlling as best we can for other value drivers, we find that valuations are significantly lower in more densely networked markets: A one-standard deviation increase in our networking 
measures is associated with an around $10 \%$ decrease in valuation, from the mean of $\$ 25.6$ million. This indicates that incumbent VCs benefit from reduced entry through paying lower prices for their investments. On the other hand, the more market share entrants can capture, the higher are the valuations paid in a market in the following year, suggesting that entry is procompetitive and, at least in that sense, benefits entrepreneurs.

Our contribution is threefold. First, we provide evidence that networking can have the effect of reducing entry in the $\mathrm{VC}$ market. We believe that our results may generalize to other industries that make heavy use of networks, such as investment banking. Second, our results help explain prior empirical evidence that better networked VCs enjoy better performance (see Hochberg, Ljungqvist, and $\mathrm{Lu}(2007))$. Part of the explanation for this may be due to the lower prices VCs pay for their investments in more densely networked markets. Third, we shed light on the process of entry in the VC industry. Successful entry appears to involve "joining the club" by offering the incumbents syndication opportunities in one's home market. This is interesting in light of Lerner's (1994) observation that "the process through which some of the entrants joined the core of established venture organizations remains unclear."

\section{Sample and Data}

Most of our data comes from Thomson Financial's Venture Economics (VE) database. We consider all investments in U.S. companies made by U.S. based VC funds between 1975 and 2003 that are included in the VE database. We exclude investments by angels and buyout funds.

\section{A. Market Definitions}

Sorenson and Stuart (2001) show that VCs tend to specialize in a certain industry and to invest locally, not least because $\mathrm{VC}$ investments require substantial monitoring and active management. Thus, the VC industry appears to be segmented into industry-specific, localized 
markets. We use the six broad industry groups defined by Venture Economics ${ }^{3}$ and cross each with either states or metropolitan statistical areas (MSAs), giving two alternative market definitions. States usually cover larger geographic areas, resulting in a broader market definition, while MSAs can usefully aggregate economic activity across borders (e.g., the tristate area around New York City). In practice, our results are nearly identical using either definition.

For inclusion in the sample, a market-year must have a history of at least 25 investments in the prior five years (to exclude markets with no real history of VC investment) and at least five VC deals in the year of analysis (to exclude inactive markets). This results in 129 distinct state/industry markets and 130 distinct MSA/industry markets. Our panels have between one and 24 annual observations for each market. The state/industry and MSA/industry panels are nested in the sense that there are multiple industries for each location in year $t$, and vice versa for each industry. The total number of market-years is 1,375 using states and 1,292 using MSAs.

\section{B. Incumbents and Entrants}

We define incumbents as VC firms that have invested in the target market at some time prior to year $t$ and continue to have investments in the market as of year $t$. Entrants are defined as VC firms that invest in the market for the first time in year $t{ }^{4}$ Entrants are not necessarily inexperienced "rookies"; for the most part, they are themselves incumbents in other markets, and they may well be more experienced than the marginal incumbent in the target market.

To measure the extent of entry in a market in year $t$, we code four variables:

\footnotetext{
${ }^{3}$ Of the 19,012 portfolio companies in the sample, 40.6\% are "Computer related", $25.3 \%$ are "Non-hightechnology," $15.4 \%$ are "Communications and media," 9.4\% are "Medical, health, life sciences," 5.4\% are "Semiconductors, other electronics," and 3.8\% are "Biotechnology."

${ }^{4}$ For robustness purposes, we also consider as entrants firms for which some amount of time has passed since their last investment in a market. Our results are robust to considering a range of time limits on prior investment history.
} 
(a) the number of deals lead-managed by entrants in the market; ${ }^{5}$

(b) the number of entrants in the market;

(c) the number of entrants that lead-manage deals in the market; and

(d) the fraction of deals lead-managed by entrants in the market.

Table I, Panel A reports descriptive statistics for entrants and incumbents, separately for state/industry and MSA/industry markets. In the median state-market-year, there are 15 incumbents and nine entrants, five of which enter by leading syndicates for one deal each, giving a combined market share of $28.6 \%$. In the median MSA-market-year, there are 16 incumbents and eight entrants, four of which enter by leading one deal each with a market share of $25 \%$.

\section{Market-level Network Measures}

Social network analysis provides a convenient way to measure how interconnected incumbents are in a market. ${ }^{6}$ Consider the markets shown in Figures 1 and 2. Figure 1 graphs the network that arises from syndication of investments in computer-related companies located in Michigan over the five-year window 1979-1983. Nodes represent VC firms and arrows represent syndicate ties. ${ }^{7}$ Arrows point from the VC leading a syndicate to the non-lead member. (Twoheaded arrows indicate that each VC has led a syndicate in which the other was a non-lead member.) Figure 2 shows the non-high-tech VC network in Pennsylvania in 1990-1994. Visual inspection suggests that the network in Figure 1 is dense; every VC firm has at least one tie to one or more VCs. In contrast, the network illustrated in Figure 2 is sparse; only two of the VC firms in this market have a tie to another VC.

\footnotetext{
${ }^{5}$ In common with the VC literature, a deal is defined as a collection of investments in a given portfolio company in a specific round of financing. We identify the lead as the investor making the largest investment in the round.

${ }^{6}$ See Wasserman and Faust (1997) for a detailed review of network analysis methods. See Hochberg, Ljungqvist, and $\mathrm{Lu}(2007)$ for an application to venture capital.

${ }^{7}$ Venture Economics distinguishes between VC funds and management firms. A VC fund has a limited (usually tenyear) life, so we assume relationships reside at the level of the $\mathrm{VC}$ firm.
} 
Networks can be represented in matrix form. Cells reflect whether two VCs co-invested in the same portfolio company, and can be coded in one of two ways. The "undirected" matrix records as a tie any participation by both VC firms $i$ and $j$ in a syndicate. The "directed" matrix differentiates between syndicates led by $\mathrm{VC} i$ versus those led by $\mathrm{VC} j .{ }^{8}$ (Figures 1 and 2 illustrate directed networks.) A natural measure of how interconnected incumbents are is the proportion of all logically possible ties that are actually present in their market, called density. For example, the maximum number of undirected ties among three incumbents $\mathrm{A}, \mathrm{B}$, and $\mathrm{C}$ is three - everyone is tied to everyone else. If only $\mathrm{A}$ and $\mathrm{C}$ are connected to each other, the density is $1 / 3$ (one tie out of the three possible).

Formally, in an undirected network of $n$ actors, the number of logically possible ties is $1 / 2 n(n-$ $1)$; in a directed network, it is $n(n-1)$. Let $p_{i j m}=1$ if at least one syndication relationship exists between VCs $i$ and $j$ in market $m$, and zero otherwise. Then the density of the undirected network equals $\Sigma_{j} \Sigma_{i} p_{i j m} /(n(n-1))$. Let $q_{i j m}=1$ if at least one syndication relationship exists in market $m$ in which $\mathrm{VC} i$ was the lead investor and $\mathrm{VC} j$ was a syndicate member, and zero otherwise. The density of the directed network then equals $\Sigma_{j} \Sigma_{i} q_{i j m} /(n(n-1))$.

In common with the industrial organization literature, we focus on relationships among the dominant incumbents and ignore ties among the competitive fringe, reasoning that the latter do not reflect an attempt to deter entry. We classify an incumbent as dominant if the VC firm is among the group of firms that contribute the first $80 \%$ of invested dollars in the target market measured over the prior five-year window; our results are not sensitive to this choice of cut-off.

VC firms that enter a market eventually become incumbents. To capture this dynamic, we construct a new network for each market for each year $t$, using data on syndications among the

\footnotetext{
${ }^{8}$ Unlike the undirected matrix, the directed matrix does not record a tie between VCs $j$ and $k$ who were members of the same syndicate if neither led the syndicate in question.
} 
incumbents over the five years ending in $t$ - 1 . Table I, Panel B reports descriptive statistics. The density of directed and undirected ties in the average state/industry market is $2.1 \%$ and $7.8 \%$ of its theoretical maximum, respectively (densities computed for MSA/industry pairs are somewhat larger). To illustrate, the Massachusetts biotech industry typifies a densely networked market; it ranks among the highest symmetric-density markets in every year in our panel. The New York non-high-tech industry, on the other hand, is the least densely networked market in most years.

\section{Market Characteristics}

The level of entry we observe in the data is an equilibrium outcome of the interaction of the potential demand for and the potential supply of VC capital. Both are difficult to observe and hence challenging to measure. To proxy for demand and supply factors that affect the entry decision, our models include a range of controls, summarized in Table I, Panel C.

Better investment performance in a particular target market may attract entrants. Absent data on investment returns, we follow Hochberg, Ljungqvist, and Lu (2007) and compute the fraction of incumbent portfolio companies in a market that were successfully exited through an IPO or an M\&A transaction between $t-5$ and $t-1$. We then compute the target market's excess exit rate as the market exit rate relative to the median exit rate across all markets in the same industry in that five-year window. This averages $4.7 \%$ in state markets and $15.1 \%$ in MSA markets.

Markets with more volatile deal flow may provide more opportunity for entry if incumbents cannot easily meet unexpected increases in demand. To proxy for swings in market demand, we compute the coefficient of variation of the monthly number of deals over the prior five years. The average market has a coefficient of variation of 1.161 (state) or 1.173 (MSA).

Larger markets and those less economically developed generally have a higher demand for external capital and more capacity for new VC funding, and thus are more likely to attract 
entrants. We use the number of deals completed in a market in year $t$ - 1 as a proxy for market size. This averages 37.9 deals in state-markets and 28.6 deals in MSA markets. To proxy for a state's economic development, we include both its gross state product (GSP), as reported by the U.S. Department of Commerce's Bureau of Economic Analysis (BEA), and its annual GSP growth rate. For MSAs, we use data for the state or states the MSA is located in. Since our sample covers more than 20 years of data, we use the BEA's implicit GNP deflator to adjust for inflation. Real GSP in the mean state/industry market is $\$ 323$ billion with a growth rate of 3.3\%, compared to $\$ 547.6$ billion in the mean MSA/industry market with a growth rate of $3.6 \% .{ }^{9}$

Certain types of deals are more likely to be syndicated, such as larger and later-stage investments (Lerner (1994), Brander, Amit and Antweiler (2002)). Thus, in markets where deals are typically syndicated, incumbents might reduce entry simply by refusing to syndicate with entrants. To capture this possibility, we calculate the fraction of deals in a market that were syndicated in the prior five years. This averages $42.5 \%$ in the average state/industry market and $47.2 \%$ in the average MSA/industry market.

Investment opportunities are a reasonable proxy for a demand-side factor affecting entry. Controlling for investment opportunities in a private market is not easy. We follow Gompers and Lerner (2000a) who use public-market pricing multiples as a proxy for private-market investment climates. Specifically, we construct annual book-to-market ratios from Compustat data for each of the six Venture Economics industries. The mean value-weighted industry book-to-market ratio in our data is around 0.5 . This variable varies by year and industry but not by state or MSA.

If $\mathrm{VC}$ firms raise funds in response to perceived investment opportunities in a particular industry, fund inflows are another useful proxy for the industry investment climate. Real VC

\footnotetext{
${ }^{9}$ Larger states tend to have more MSAs and so are overweighted in this particular summary statistic.
} 
fund inflows average around $\$ 7$ billion per year and industry over the sample period.

Many start-up companies develop and commercialize cutting-edge technologies, and so require skilled and educated workers. Education levels in a particular geographic region may hence be related to the probability of entrepreneurial success and consequently to the supply of VC funding. We obtain data on annual state-level science and engineering degree completions from the National Science Foundation (NSF).$^{10}$ This averages 2.6 per a thousand inhabitants.

\section{E. Characteristics of Potential Entrants}

All else equal, we expect more entry if there is a larger pool of "qualified" potential entrants (see Berry (1992)). A VC firm is considered to be a potential entrant if (1) it was founded in or before year $t$; (2) it has at least one fund under management that was raised in the previous six years; and (3) it has not invested in this particular market prior to year $t .{ }^{11}$ We consider three key characteristics of potential entrants.

$\mathrm{VC}$ investments require substantial monitoring and active management and so tend to be local. We therefore control for the geographic distance between each potential entrant's location and the target market. Following Coval and Moskowitz (1999), we compute the geographic distance for each pair of $\mathrm{VC} i$ and target market $m$ as follows:

$$
\begin{aligned}
D_{\text {im }} & =\arccos \left\{\cos \left(\text { lat }_{i}\right) \cos \left(\text { lon }_{i}\right) \cos \left(\text { lat }_{m}\right) \cos \left(\text { lon }_{m}\right)+\right. \\
& \left.\cos \left(\text { lat }_{i}\right) \sin \left(\text { lon }_{i}\right) \cos \left(\text { lat }_{m}\right) \sin \left(\text { lon }_{m}\right)+\sin \left(\text { lat }_{i}\right) \sin \left(\text { lat }_{m}\right)\right\} 2 \pi r / 360
\end{aligned}
$$

where lat and lon are the latitudes and longitudes (measured in degrees of arc) and $r$ is the radius

\footnotetext{
${ }^{10}$ Science and engineering includes the following subjects: Engineering, physical sciences, geosciences, mathematics and computer sciences, life sciences, and science and engineering technologies.

${ }^{11}$ Condition (2) ensures that we capture active funds. A typical VC fund spends its first few years nurturing portfolio companies and the remainder of its life exiting them (Ljungqvist and Richardson (2003)).
} 
of the earth $(\approx 3,963$ miles $) .{ }^{12}$ We then compute the fraction of potential entrants that are located within 100 miles of the target market. (Our results are robust to alternative cut-offs.)

Presumably, prior investment experience in the industry or state/MSA help a potential entrant enter a market. Thus, we assign potential entrants to four groups based on their industry and geographic investment patterns in the prior five years. In the mean state market, $6.8 \%$ of potential entrants have previously invested in both the industry and state, $31 \%$ have invested in the industry before but not in the state, $5.9 \%$ have invested in the state but not in the industry, and the remainder in neither. Figures for MSA markets are similar; see Table I, Panel D.

A key question we address is whether an entrant's prior relationships with incumbents, established in other markets, can facilitate entry. For each potential entrant, we generate indicator variables capturing whether, in the prior five years, the potential entrant (a) participated in a deal lead-managed by an incumbent; or (b) lead-managed a deal in another market in which an incumbent was a co-investor. In the jargon of network analysis, these correspond to positive indegree and outdegree, respectively. In the average market-year, around $20 \%$ of potential entrants have served as co-investors for incumbents elsewhere during the prior five years, while around $13 \%$ have lead-managed syndicates in which incumbents were co-investors.

\section{Market-Level Analysis}

\section{A. A Descriptive Model of Entry in Venture Capital}

To see if the data support a link between the extent of entry in a VC market and the density of the incumbents' network ties, we regress the number of deals entrants win in year $t$ in market $m$ on the networking measure for the market as of year $t-1$ and suitably lagged controls for the pool of qualified potential entrants and the aforementioned market characteristics. We have two

\footnotetext{
${ }^{12}$ We use zip codes to identify the coordinates of a VC's headquarters, assuming it is located in the center of the zip code area. To find the coordinates of a market, we use the modal zip code of all portfolio companies in the market.
} 
alternative network measures (asymmetric and symmetric density) and two alternative market definitions (using states and MSAs), resulting in four specifications. ${ }^{13}$ Given the count nature of the dependent variable, and the fact that we have repeated observations per market, the models are estimated using conditional fixed-effects Poisson. We also include year fixed effects.

Table II reports the resulting estimates. The pseudo- $R^{2}$ exceeds $50 \%$ indicating good explanatory power. In each of the four specifications, we find a strongly negative and significant relation between the extent of networking and the number of deals entrants win, consistent with our conjecture that networking can help deter entry. As we control separately for whether deals are typically syndicated in the market, networking likely captures more than a straightforward refusal to syndicate a deal with an entrant.

The controls behave as expected. There is significantly more entry if there is a larger pool of qualified potential entrants for the market, in the sense of geographic proximity to the market or prior investment experience (especially having invested both in the area and the industry). ${ }^{14} \mathrm{~A}$ greater prevalence of past network ties between potential entrants and incumbents also makes entry more likely, giving a first indication that entry indeed involves a measure of reciprocity: By sharing its deal flow today, a VC firm may gain access to another market at a later date.

As for the market characteristics, as expected, the number of deals entrants win increases in investment opportunities (as proxied by industry book-to-market ratios), variability of demand, flows of capital into the industry, and the size of the VC market (as measured by the number of deals in the previous year). There is less entry in larger states (based on state GSP) and (using the MSA definition) in states with more science and engineering graduates. Entry is unrelated to the

\footnotetext{
${ }^{13}$ In a previous draft, we included two further popular network measures, namely "degree" and "eigenvector", with qualitatively similar results (available on request).

${ }^{14}$ Sensibly, experience in the state or MSA by VCs focused on other industries is associated with less entry.
} 
market's lagged performance history, the number of incumbents, and GSP growth.

\section{B. Omitted Variables and Causality}

Table II provides evidence of a link between the extent of entry in a VC market and the density of the incumbents' network ties, but the correlation could well be spurious. A first-order concern is that some omitted variable simultaneously makes networking more advantageous and entry less desirable, making networking endogenous. An obvious example is the cost of doing business in a given market. VCs might network to reduce cost; at the same time, high-cost markets may attract less entry. In this case, the results in Table II would overstate the effect of networking on entry. The reverse is also possible. Suppose we have inadequate controls for investment opportunities. In markets with poor investment opportunities, VCs may be less keen to share their deals, while entry is also less attractive. In this case, the results in Table II would understate the effect of networking on entry.

Table II includes market fixed effects, which takes care of time-invariant market-specific omitted variables. To examine whether our results are biased due to time-varying omitted variables, we adopt two approaches. The first uses instrumental variables to deal directly with the potential endogeneity of networking; the second approach exploits the nested panel structure of our data to construct proxies for two likely types of omitted variables.

\section{A Two-stage Model of Market-level Entry}

Our first approach uses two instruments chosen to satisfy the exclusion restriction; that is, the instruments likely correlate with the extent of networking but are unlikely to affect entry directly.

\section{C.1. Geographic Clustering of Demand}

If more frequent interaction helps VCs form ties, it is more likely that dense networks will result. Markets in which demand is spread uniformly over a wide geographic area presumably 
offer fewer opportunities for VCs to interact than markets in which demand is concentrated in a few clusters of economic activity. Silicon Valley is an obvious case in point. More generally, VCs tend to meet while in town to attend board meetings of their portfolio companies (Kuemmerle and Ellis (1999)) and during "pitch events" for local startups seeking capital. The more clustered are portfolio companies and start-ups, the greater the chances that any two VCs will meet and establish a relationship. Thus, our first instrument is based on the geographic distribution of demand in a market, measured as the entropy of the number of investments per zip code area in the market. ${ }^{15,16}$ The more unequal the distribution, the lower the entropy.

\section{C.2. Presence of Corporate VCs}

For reasons unrelated to entry considerations, markets with a heavy presence of corporate venture programs are likely to be less densely networked. According to Gompers and Lerner (2000b), corporate VCs differ from traditional VCs both in terms of investment objectives (which are often strategic rather than financial) and their longevity (which averages a mere four years). This alone makes them less likely to view networking as a way to reduce long-run entry into a given market: It may be something they are content to free-ride on, but their incentives to contribute to entry deterrence - for instance, by carrying out costly punishment strategies - are clearly much lower. Corporate VCs also tend to form less dense syndication networks, for a simple reason. Because of compensation issues, they are typically staffed with managers seconded from the parent corporation, as opposed to dedicated venture capital professionals (Gompers and Lerner (2001)). These individuals are likely to be considerably less well networked (at the personal level) than are dedicated VC professionals, and this tends to lead to

\footnotetext{
${ }^{15}$ Denote by $N$ the number of investments in a market in the prior five years, and $n_{\mathrm{i}}$ the number of such investments in zip code area $i$. Then the market's entropy equals $\Sigma_{\mathrm{i}} n_{\mathrm{i}} / N \ln \left(1 /\left(n_{\mathrm{i}} / N\right)\right)$.

${ }^{16}$ In a previous draft, we used the coefficient of variation of the distance between each pair of portfolio companies in a market, calculated using equation (1). This produces marginally stronger results, available on request.
} 
opportunistic as opposed to strategic syndication.

Thus, the presence of corporate VCs in a market is expected to be associated with lower levels of networking, a prediction borne out empirically in Zheng (2004). At the same time, it is hard to see why the presence of corporate VCs should encourage or deter entry directly.

\section{C.3. First-stage Results}

The first-stage regression in our IV models predicts the extent of networking in the market as a function of the two instruments, the second-stage control variables (as per Table II), and market and year fixed effects. Table III reports the estimates for each of the four specifications. Overall, the models appear to be well specified: The within-group $R^{2}$ in each exceeds $50 \%$.

Having valid instruments that satisfy the exclusion restriction is not sufficient to ensure unbiased two-stage estimators in finite samples; the instruments also need to correlate 'strongly' with the endogenous first-stage variable. The $F$-tests suggest our instruments are collectively strong in three of the four models, using Staiger and Stock's (1997) recommended critical value of 10. (The $F$-statistic of 7.5 in the asymmetric density model with MSA markets is borderline.) Consistent with our hypothesis that markets in which demand is concentrated geographically experience more networking, we find that the entropy of demand is negatively and significantly related to both density measures under both market definitions. The same is true of the fraction of corporate VCs in a market (except when we model symmetric density in MSA markets).

\section{C.4. Determinants of Market Entry: Second-stage Results}

Table IV presents the results of the instrumental-variables entry models. The dependent variables in Panels A, B, and C are the number of deals won by new entrants in year $t$, the number of VC firms entering a market, and the number of VCs entering as lead-managers, respectively. As in Table II, we estimate conditional fixed-effects Poisson models, though we 
now instrument the networking measures using predicted values from Table III. The dependent variable in Panel D is the fraction of deals by number lead-managed by entrants, which has support on $[0,1]$ and positive mass at both 0 and $1 .{ }^{17}$ To avoid the well-known biases of OLS in this situation, we estimate fractional logit models using quasi-MLE, modeling the conditional mean as $\mathrm{E}(\mathrm{y} \mid \mathrm{x})=\exp (\mathrm{x} \beta) /(1+\exp (\mathrm{x} \beta))$; see Papke and Wooldridge (1996). As fractional logits cannot currently accommodate fixed effects, Panel D pools repeated observations on each market. To conserve space, we report only the coefficients for the instrumented network measures and the $R^{2}$; the coefficients on the controls mirror those shown in Table II.

As before, we find a negative and statistically significant relation between networking and the number of deals won by entrants. ${ }^{18}$ Comparing Table II to Panel A of Table IV, it is clear that failure to account for endogeneity imparts a positive (i.e., attenuating) bias to the point estimates. This suggests that the omitted variable or variables simultaneously make networking and entry more desirable. On net, they are thus of the omitted-investment-opportunities variety, rather than the omitted-cost type.

The economic effect of networking is large. At the means of the other covariates, a onestandard deviation increase in asymmetric density, for instance, reduces the expected number of deals entrants win in state markets by 1.5. This is large compared to the median of five. The predicted difference in the number of deals won in the least and most networked markets is 9.7. (In general, the economic effects are somewhat smaller when we consider MSA markets, though as Table I shows, so is the extent of entry. For instance, in Panel A, the corresponding number for the two MSA specifications is around four.) Networking has the third largest economic effect

\footnotetext{
${ }^{17}$ We obtain qualitatively similar results when we instead use the fraction of deals by value won by entrants.

${ }^{18}$ Consistent IV standard errors are obtained using the procedure derived in Murphy and Topel (1985, Section 5).
} 
in this specification, after variation in investment opportunities and state GSP.

Similar results obtain for the other three measures of entry. Both the overall number of entrants and the number of entrants that lead syndicates are negatively and significantly related to networking. The effects are again large economically. In Panel B, for instance, a one-standard deviation increase in asymmetric density is associated with a decrease of 2.9 in the number of entrants in state/industry markets (compared to a median of nine). The corresponding effect in Panel C, which focuses on the number of VC entering as lead investors, is 1.3, compared to a median of five. In Panel D, we find that entrants' combined market share is likewise significantly lower in more networked markets, and the economic effect is again quite large. A one-standard deviation increase in network density reduces the fraction of deals lead-managed by entrants by between $9.7 \%$ and $11.4 \%$ from the unconditional mean, depending on the specification.

Collectively, the results from the market-level entry models shown in Table IV suggest that even after accounting for the endogeneity of networking in the target market, networking by incumbents can present a barrier to entry for potential entrants, and thus may restrict the competitive supply of venture capital to entrepreneurial firms.

\section{Correction for Omitted Variables}

How persuasive the IV results are depends on how plausible our instruments are judged to be. The nested structure of our panel allows us to investigate the effects of omitted variables without relying on instruments. Suppose the omitted variables, currently subsumed in the error terms of the networking and entry equations, are of the form $\gamma_{l t}+\delta C_{s t}$, where $l$ indexes locations (state or MSA) and $s$ indexes industries. In other words, suppose the omitted variables are time-varying factors that are location-specific or industry-specific. Then, density 
$D_{l s t}=\beta X_{l s t}+v_{l s t}=\beta X_{l s t}+\gamma C_{l t}+\delta C_{s t}+\varpi_{l s t}$. Under this quite general assumption, ${ }^{19}$ we can construct a proxy for $C_{l t}$ using only observables. Specifically, we subtract from $D_{l s t}$ its average across locations, holding industry constant, and solve for $C_{l t}$. Because $\mathrm{C}_{s t}$ doesn't vary across locations, it cancels out and we obtain a proxy for $C_{l t}$ that is a function of observables and a constant term (mean $C_{l t}$ ) which is subsumed in the market fixed effects:

$$
C_{l t}^{*}=\gamma C_{l t}+\varepsilon_{l s t}=\left(D_{l s t}-\frac{1}{N_{l t}} \sum_{l} D_{l s t}\right)-\left(\beta X_{l s t}-\frac{\beta}{N_{l t}} \sum_{l} X_{l s t}\right)+\frac{\gamma}{N_{l t}} \sum_{l} C_{l t}+\varepsilon_{l s t}
$$

Estimates of $\beta$ can be obtained from a regression of $D_{l s t}$ on observables $X_{l s t}$. The proxy for $\mathrm{C}_{s t}$ is constructed analogously. The two proxies are then included in the entry equation to reduce the bias-inducing correlation between the networking variable and the disturbances.

Table $\mathrm{V}$ presents the results of the augmented entry models for the same four entry measures as in Table IV. In each of the 16 specifications, the effect of networking on entry is negative, and it is statistically significant at the $5 \%$ level in 13 of the 16 models and at the $10 \%$ level in 15 . The coefficient estimates are similar in magnitude to those in the IV models in Table IV, and larger (more negative) than those in the naïve models shown in Table II. Though not reported, the coefficients estimated for $C_{l t}^{*}$, the proxy for location-specific omitted factors, are consistently positive and statistically significant; the coefficients for $C_{s t}^{*}$ are never significant. The relevant omitted variable is hence location-specific, and the sign suggests it captures something that makes both networking and entry more desirable (such as omitted investment opportunities).

In sum, both the IV approach and the omitted variables correction support the interpretation that more densely networked markets are associated with less entry, even after accounting for

\footnotetext{
${ }^{19}$ Bearing in mind that we include market fixed effects, the only type of omitted variable we cannot capture this way is one that varies simultaneously across time, location, and industry.
} 
possible omitted variables that make networking endogenous to entry.

\section{Firm-level Analysis}

We now turn to the entry decision of an individual potential entrant. This sheds light on how determined entrants can overcome networking-related entry barriers. Specifically, we explore whether an entrant can soften the reaction it receives in a market by first establishing ties to one or more of the incumbents in its own home market. We distinguish between the case where a potential entrant has previously invited an incumbent to be a participant in a syndicate in its home market (positive outdegree) and the case where a potential entrant was a junior investor in a multi-market incumbent's syndicate in another market (positive indegree).

Table VI presents summary information on the characteristics of potential entrants in the 129 state markets (results for MSA markets look similar). Panel A shows that VC firms with prior ties to incumbents are more than three times more likely to enter a market than are other potential entrants, whether we focus on outdegree or indegree. This supports the notion that reciprocity is an important part of a successful entry strategy in venture capital.

Panels B and C show that investors located closer to a target market and those that have previous industry-related and/or geographic experience are consistently more likely to enter a market than are other potential entrants. This mirrors the market-level results of the previous section. For example, the entry rate among VCs headquartered within 100 miles of the center of the target market is $5.01 \%$ in a given year, compared to $1.28 \%$ among those located further away. ${ }^{20}$ Similarly, the entry rate for potential entrants with both previous industry and state investment experience is $4.42 \%$, compared to $1.21 \%$ among other VCs. ${ }^{21}$

\footnotetext{
${ }^{20}$ As above, we define the center as the modal location of portfolio companies (in a given industry) in the state. Our results are not sensitive to the 100-mile cutoff. However we measure it, closer VCs are more likely to enter.

${ }^{21}$ Similar patterns obtain if we define entrants as firms that enter as lead investors rather than syndicate members.
} 
To control for other influences on the entry decision, we estimate firm-level probit models in which the dependent variable equals one if the potential entrant enters the market successfully and zero otherwise. The main variables of interest are the density of incumbents' relationships in the target market and a set of indicators for the variables considered in Table VI: Proximity to the market, previous investment experience, and prior ties to incumbents. Other controls include the size of the VC firm and the performance history, investment opportunities, demand variation, market size, overall supply of VC capital, and state economic development measures described in Section I. Adding the omitted-variable proxies $C_{l t}^{*}$ and $C_{s t}^{*}$ has no effect on the results.

The results are reported in Table VII. As before, there are four models, based on two alternative network measures and two alternative market definitions. The models have good overall fit, with pseudo $R^{2}$ of around $16 \%$. In each specification, we find that a potential entrant is significantly less likely to enter the more networked the market. This mirrors the main result of the market-level models discussed in Section II.

Who does enter? Prior ties to incumbents have a positive and significant effect on the likelihood of entry in all four models, for both indegree and outdegree. Thus, successful entrants are those who have syndicated with target-market incumbents in other markets. The models include interaction terms crossing indegree and outdegree with the networking measures, and these are each positive and mostly statistically significant. Thus, for entrants with suitable connections, the extent of networking in the target market appears to be irrelevant. To explore this idea more formally, we test the following linear restrictions:

- $\quad$ network measure $\cdot(1+$ indegree $)=0$

- $\quad$ network measure $\cdot(1+$ outdegree $)=0$

- $\quad$ network measure $\cdot(1+$ outdegree + indegree $)=0$ 
In none of the four models in Table VII are the combined effects significantly negative, suggesting that networking presents a significant barrier to entry only for entrants that lack ties to any incumbent. In fact, entrants with both positive indegree and positive outdegree are actually significantly more likely to enter the more densely networked the market. ${ }^{22}$

Larger VC firms, measured by capital under management since inception, are significantly more likely to enter. While size might proxy for a range of relevant characteristics, entry by large VC firms may be more likely to be accommodated because big players can offer greater rewards in the form of syndication opportunities in their home markets.

The single most significant determinant of the entry decision in Table VII is location. Depending on specification, VC firms located within 100 miles of the center of the target market are between $126 \%$ and $143 \%$ more likely to enter than those located farther away. Previous related investment experience, whether in the area or the industry or both, is similarly helpful. Economically, these effects too are large. For instance, prior experience in the industry and state increases the likelihood of entry by around 1.8 percentage points from the unconditional mean of $1.5 \%$, an increase of around $120 \%$. Prior industry experience in the absence of prior investments in the state has a smaller economic effect, increasing the likelihood of entry by around $36 \%$, while experience in the state but not the industry increases it by $29 \%$. The effects of the remaining control variables largely mirror those found in the market-level analysis.

\section{Strategic vs. Efficient Networking}

Suppose there are two markets, configured as follows: Market $1=[\mathrm{VC} 1 \mathrm{VC} 2 \mathrm{VC} 3]$ and

\footnotetext{
${ }^{22} \mathrm{An}$ interesting related question is who entrants syndicate with when they enter. Our data show that entrants are more likely to syndicate with incumbent VC firms that they have done business with elsewhere before. Specifically, we find that the probability that an entrant syndicates with a related incumbent is $18.3 \%$. The median probability under the null that pairings conditional on entry are random is $10.8 \%$, based on 200 draws from a bootstrapped sample. The observed and simulated probabilities are significantly different at $p<0.0001$.
} 
Market $2=$ [VC4 VC5]. Let $\mathrm{x}$ be the unconditional probability that VC5 enters Market 1 . Based on our findings in the previous section, if VC3 does a deal with VC5 in Market 2 (VC5's home market), this increases the probability that VC5 will enter Market 1 , say to $\mathrm{x}+\mathrm{y}$. This increase in the threat of entry should elicit a strategic response from $\mathrm{VC} 1$ and $\mathrm{VC} 2$, the other incumbents of Market 1 . We would expect them to try to reduce the attractiveness of entry, most obviously by cutting VC3 out of the loop (informationally, etc.), so as to neutralize the link VC5 has made into their market. Testing for such a response allows us to distinguish between strategic reasons to network (i.e., intentionally making entry harder) and efficient reasons to network (i.e., to save on costs while accidentally making entry harder) ${ }^{23}$

Empirically, we perform a difference-in-difference test, comparing the difference over time in each incumbent's participation in its home-market network as a function of whether or not the incumbent has done business with a potential entrant in another market. The unit of observation is thus an incumbent VC firm, $i$. The dependent variable is the change in the probability that firm $i$ is invited to join a syndicate lead-managed by another incumbent operating in its market. The main variable of interest is an indicator set equal to one if firm $i$ co-syndicated with a potential entrant in another market during year $t$-1. We test the hypothesis that the other incumbents in $i$ 's home market react by excluding it from some or all of their syndicates for a period of time.

As strategic behavior invites free-riding, we expect the likelihood and severity of punishment to be greater the fewer incumbents are active in the market. Hence we interact the variable of interest with an indicator set equal to one if there are five or fewer incumbents in the market. (Our results are not sensitive to other reasonable cut-offs.) To allow for flexibility in the duration of punishment, we compute the change in syndication probability from year $t$ to each of the next

\footnotetext{
${ }^{23}$ This test is biased against us. VC3 will only do business with VC5 if it expects the other incumbents' response to be relatively lenient - which will make it harder to detect such a response in the data.
} 
five years. Note that VC firms entering after year $t$ (i.e., future incumbents) are not included in this calculation, as they cannot plausibly punish VC firm $i$ for causing entry to become easier before they themselves entered. We also screen out markets with a monopolist incumbent, as there can be no strategic response.

Table VIII reports the results. With two market definitions (state and MSA) and a five-year window, we estimate ten OLS regressions. Each controls for year and industry effects as well as two VC firm characteristics: Size and degree, a measure of network centrality. We expect larger and better connected VCs to face more lenient reactions.

As expected, the effect on a VC firm's inclusion in other incumbents' syndicates of having done business with a potential entrant is negative, but not significantly so unless the market has a small number of incumbents. Combining the direct and interaction effects, doing business with a potential entrant reduces the probability of inclusion in home-market syndicates the next year by 1.1 percentage points $(=-0.313-0.806)$ in state markets and 2.2 percentage points in MSA markets with five or fewer incumbents. The unconditional probability in year $t$ is $4.8 \%$ and $5.9 \%$, respectively, so the reduction is large economically. In other words, incumbents appear to respond strategically to an increased threat of entry. The strategic response is not only large, it is persistent and its extent increases over time. In state markets, an incumbent that has done business with a potential entrant can expect to see its home-market syndication opportunities decrease by $2.3,3.5,3.4$, and 4.3 percentage points after two, three, four, and five years, respectively. (For MSA markets, the response peaks after four years, at -4.6 percentage points.)

\section{Valuation Effects}

Our results support the hypothesis that strategic networking deters at least some entrants. As a result, we expect incumbent VCs to exploit their increased bargaining power by negotiating 
more favorable funding terms at the expense of entrepreneurs. Because we do not observe any qualitative funding terms (such as control rights, liquidation preferences, anti-dilution protection, and so on), we focus on the valuations at which venture-backed companies raise VC funding.

Companies typically receive funding in distinct stages, which provides VCs with the option to cease funding if a business model turns out not to work. Not surprisingly, the average company's valuation increases over a sequence of funding rounds and with its maturity. It also appears to be related to networking. Sorting state markets into quartiles based on asymmetric density, for instance, the average real valuation is $\$ 10.6$ million in the most densely networked markets versus \$20.4 million in the least densely networked ones.

These figures do not control for other reasons why valuations might differ. Table IX reports OLS regression results where the unit of analysis is a funding round and the dependent variable is the $\log$ of the round valuation. The explanatory variables of interest are the density measures; the fraction of deals entrants won in the company's market the previous year; and an indicator identifying whether the company's lead investor is an entrant $(=1)$ or an incumbent $(=0)$. If entry deterrence is effective, we expect lower valuations in more densely networked markets. Where entrants manage to overcome the entry barriers put in their way, we expect higher valuations. Finally, entrants likely have to offer higher valuations to compete with incumbents.

Absent data on sales, earnings, or book values in the Venture Economics database, there are no company-specific value drivers we can control for beyond stage of development and funding round number. Following Gompers and Lerner (2000a), we instead control for the book-tomarket ratio of the company's industry (to proxy for investment opportunities), a valuation index of publicly listed companies in the same industry, constructed as in Gompers and Lerner (2000a), and the amount of money raised in the previous year by VC funds focusing on the company's 
industry (to capture any "money chasing deals" phenomena). We also include a proxy for the lead investor's investment experience (the log size of assets under management), the lagged number of deals completed in the company's market, an indicator identifying seed- or early-stage companies, a set of funding round dummies (the omitted category is a first-round investment), and market fixed effects to control for otherwise unobserved heterogeneity across markets, such as local pricing anomalies, conditions in the managerial labor market, and so on.

As in Section II.D, we augment the regression with the omitted variable proxies $C_{l t}^{*}$ and $C_{s t}^{*}$, to allow for the possibility that time-varying factors that are either location-specific or industryspecific influence both the networking decision and valuations in a market. An example is cost: High-cost locations may be associated with more networking and lower valuations.

The resulting regressions have good fit, in view of the approximately $40 \%$ adjusted $R^{2}$. Regardless of how we measure it, companies in more densely networked markets are valued significantly less highly, suggesting that incumbent VCs benefit from reduced entry through paying lower prices for their investments. Economically, a one-standard deviation increase in asymmetric or symmetric density is associated with a more than $10 \%$ decrease in round valuation from the unconditional mean of $\$ 25.6$ million, all else equal. On the other hand, the more market share entrants have captured in the recent past, the higher are the valuations paid, suggesting that entry benefits entrepreneurs through higher prices. Also, perhaps not surprisingly, entrants pay significantly higher valuations than do incumbents, all else equal.

The results for the controls mirror those in Gompers and Lerner (2000a). Higher industry valuations in the public markets are associated with higher valuations being paid in the private markets, while more money chasing deals drives valuations up significantly. Valuations are also higher in more active markets (based on the number of completed deals) and when a more 
experienced VC leads the round. Early-stage companies receive lower valuations while valuations increase significantly as a company progresses through follow-on funding rounds.

While these results support the notion that entry deterrence has real, detrimental effects for the terms on which entrepreneurs can access the VC market, the Venture Economics valuation data have two shortcomings which could lead to spurious results. First, they are self-reported, and there is every reason to expect companies to disclose valuations strategically; for instance, a company may choose not to disclose a "down-round" valuation (i.e., a discount to the previous round). Indeed, only one fifth of the funding rounds in the VE database disclose valuations.

To correct for strategic disclosure, we follow Hwang, Quigley, and Woodward (2005) who estimate an ordered probit model of seven events at which valuations could be disclosed. ${ }^{24}$ The explanatory variables are the company's development status (as per its most recent prior funding round), its VE industry group and location, the stock market capitalization at the time, year effects, and the elapsed time since the most recent funding round, the importance of which is allowed to vary with the type of the previous round (seed, late-stage, and so on). From the ordered probit estimates, they construct the inverse Mill's ratio for each company and round.

We replicate their model in our data and obtain results that are at least as strong as theirs (not shown). When we include the inverse Mill's ratio in the Table IX specifications, we continue to find that round valuations are lower in more densely networked markets, but increase after entrants have won more market share and if an entrant leads a round. As Panel B of Table X shows, all coefficients are highly statistically significant. Compared to the relevant coefficients from the Table IX specifications, reproduced in Panel A for ease of comparison, the selection-

\footnotetext{
${ }^{24}$ The events are: 1) Revelation of value through shutdown; 2) funding through acquisition, without revelation of value; 3) no funding at all; 4) VC funding without revelation of value; 5) VC funding with revelation of value; 6) funding through acquisition with revelation of value; 7) funding and revelation of value through an IPO.
} 
corrected model produces slightly smaller economic effects for the network measures.

The second shortcoming of the VE valuation data is the absence of company-level data on value drivers. No doubt our valuation models leave out many factors that influence valuations, such as the company's track record, the quality of management, or the strength of intellectual property. However, we can exploit the panel structure of the data - companies receive multiple funding rounds - to remove the effect of unobserved company-specific factors. We do so while continuing to control for unobserved market-specific factors that might bear on valuation. The resulting model is a mixed linear model with two levels of random effects (for the company and for the market), which can be estimated using maximum residual likelihood; see Baltagi, Song, and Jung (2001). The coefficients of interest are reported in Panel C of Table X. The likelihood ratio tests strongly reject the null that market and company-level effects are jointly zero (indeed each level is significant, though this is not shown). While some coefficients are somewhat smaller than in Panel A, we continue to find, as before, that networking significantly reduces valuations while entry increases them.

Our final models, shown in Panel D, adjust for both selective disclosure and unobserved company-level heterogeneity by including the inverse Mill's ratios in the mixed effects model. While this reduces the coefficient estimates for the networking a bit further, our conclusions remain unaffected. Thus, the effects of networking and entry on company valuations do not appear to be an artifact of well-known problems with the VE valuation data.

\section{Conclusions}

We examine whether networking among U.S. VC firms restricts entry into local VC markets, thereby improving their bargaining power over entrepreneurs. We expect more densely networked markets to be harder to enter, not only because of the relatively greater network 
externalities that incumbents enjoy in such markets, but also because withdrawal of network access may provide an effective threat of punishment against incumbents who cooperate with new entrants.

We provide evidence that markets in which incumbents maintain dense syndication networks with each other are indeed associated with reduced entry, controlling for a wide variety of other influences that bear on entry. Moreover, evidence derived from plausible instruments for networking suggests that prevailing network conditions in a target market causally influence entry decisions. The magnitude of these effects is economically large, and robust to a wide range of specifications.

One way to overcome this particular barrier to entry is through establishing ties to the incumbents in other markets, i.e., by "joining the club." The price of admission appears to be letting incumbents in on the entrant's deal flow in unrelated markets. In addition, previous investment experience in the targeted industry or a prior presence in the targeted geographic area facilitates entry. However, entrants also appear to enter by offering to pay higher prices.

While networking is no doubt motivated by efficiency considerations, its entry-reducing effects do not appear entirely accidental. Our evidence shows that incumbents react strategically to an increased threat of entry - such as when a fellow incumbent does business with a potential entrant in another market - by reducing their syndication ties to the offending VC.

Having established a link between syndication networks and reduced entry, we ask whether incumbents' bargaining power vis-à-vis entrepreneurs increases. We show that the valuations at which companies can raise $\mathrm{VC}$ funding depend on the extent of networking and the degree of entry that results, consistent with networking providing an effective barrier to entry. Our results are consistent with the hypothesis that incumbents engage in strategic behavior that reduces entry 
and benefit from doing so through paying lower prices for their investments.

Our findings illustrate the role of networking as an entry deterrent. While we focus on the VC setting, we believe our findings generalize to other industries that make heavy use of networks, such as investment banking. In addition, they help explain prior empirical evidence that better networked VCs enjoy better performance (see Hochberg, Ljungqvist, and Lu (2007)). Our work also sheds light on the process of entry. Successful entry appears to involve "joining the club" by offering the incumbents syndication opportunities in one's home market. Finally, our findings present interesting policy implications. If networking poses an effective barrier to entry, this may lead to a more restricted supply of capital to entrepreneurial ventures and to harsher funding terms. The structure of the local VC market therefore has significant implications for entrepreneurial ventures seeking startup capital. More broadly, we may ask how strategic behavior in the VC market affects the funding of new ventures and their eventual success. 


\section{References}

Baltagi, Badi H., Seuck H. Song, and Byoung C. Jung, 2001, The unbalanced nested error component regression model, Journal of Econometrics 101, 357-381.

Berry, Steven T., 1992, Estimation of a model of entry in the airline industry, Econometrica 60, 889-917.

Bonacich, Philip, 1972, Factoring and weighting approaches to status scores and clique identification, Journal of Mathematical Sociology 2, 113-120.

Bonacich, Philip, 1987, Power and centrality: A family of measures, American Journal of Sociology 92, 1170-1182.

Brander, James, Raphael Amit, and Werner Antweiler, 2002, Venture capital syndication: Improved venture selection versus the value-added hypothesis, Journal of Economics and Management Strategy 11, 423-452.

Bygrave, William D., 1988, The structure of the investment networks of venture capital firms, Journal of Business Venturing 3, 137-158.

Coval, Joshua D., and Tobias J. Moskowitz, 1999, Home bias at home: Local equity preference in domestic portfolios, Journal of Finance 54, 2045-2073

Gompers, Paul A., and Josh Lerner, 2000a, Money chasing deals? The impact of fund inflows on private equity valuations, Journal of Financial Economics 55, 281-325.

Gompers, Paul A., and Josh Lerner, 2000b, The determinants of corporate venture capital success: Organizational structure, incentives, and complementarities, in Randall Morck, editor, Concentrated Ownership. Chicago, IL: University of Chicago Press.

Gompers, Paul A., and Josh Lerner, 2001, The Money of Invention: How Venture Capital Creates New Wealth, Boston, MA: Harvard Business School Press.

Hochberg, Yael V., Alexander Ljungqvist, and Yang Lu, 2007, Whom you know matters: Venture capital networks and investment performance, Journal of Finance 62, 251-301.

Hsu, David, 2004, What do entrepreneurs pay for venture capital affiliation? Journal of Finance 59, $1805-1844$.

Hwang, Min, John M. Quigley, and Susan E. Woodward, 2005, An index for venture capital, 1987-2003, Contributions to Economic Analysis and Policy 4, 1-43.

Inderst, Roman, and Holger Mueller, 2004, The effect of capital market characteristics on the value of start-up firms, Journal of Financial Economics 72, 319-356.

Kuemmerle, Walter, and Chad Ellis, 1999, JAFCO America Ventures, Inc.: Building a Venture Capital Firm. Boston, MA: Harvard Business School Publishing.

Lerner, Josh, 1994, The syndication of venture capital investments, Financial Management 23, 16-27. 
Ljungqvist, Alexander, and Matthew Richardson, 2003, The investment behavior of private equity fund managers, Working paper, New York University.

Murphy, Kevin M., and Robert H. Topel, 1985, Estimation and inference in two-step econometric models, Journal of Business and Economic Statistics 13, 370-379.

Papke, Leslie E., and Jeffrey M. Wooldridge, 1996, Econometric methods for fractional response variables with an application to 401(k) plan participation rates, Journal of Applied Econometrics 11, 619-632.

Sah, Raj K., and Joseph E. Stiglitz, 1986, The architecture of economic systems: Hierarchies and poliarchies, American Economic Review 76, 716-727.

Sorenson, Olav, and Toby E. Stuart, 2001, Syndication networks and the spatial distribution of venture capital investments, American Journal of Sociology 106, 1546-1588.

Staiger, Douglas, and James H. Stock, 1997, Instrumental variables regression with weak instruments, Econometrica 65, 557-586.

Wasserman, Stanley, and Katherine Faust, 1997, Social Network Analysis: Methods and Applications. New York, NY: Cambridge University Press.

Zheng, Ju Kimberly, 2004, A social network analysis of corporate venture capital syndication, Working Paper, University of Waterloo. 
Figure 1. Example of a Densely Networked Market

The figure shows the network that arises from syndication of portfolio company investments in the market for computer-related ventures in Michigan over the five-year window 1979-1983. Nodes on the graph represent VC firms, and arrows represent syndicate ties between them. The direction of the arrow represents the lead/non-lead relationship between syndicate members. The arrow points from the VC leading the syndicate to the non-lead member. Two-directional arrows indicate that both VCs on the arrow have at one point in the time window led a syndicate in which the other was a non-lead member.

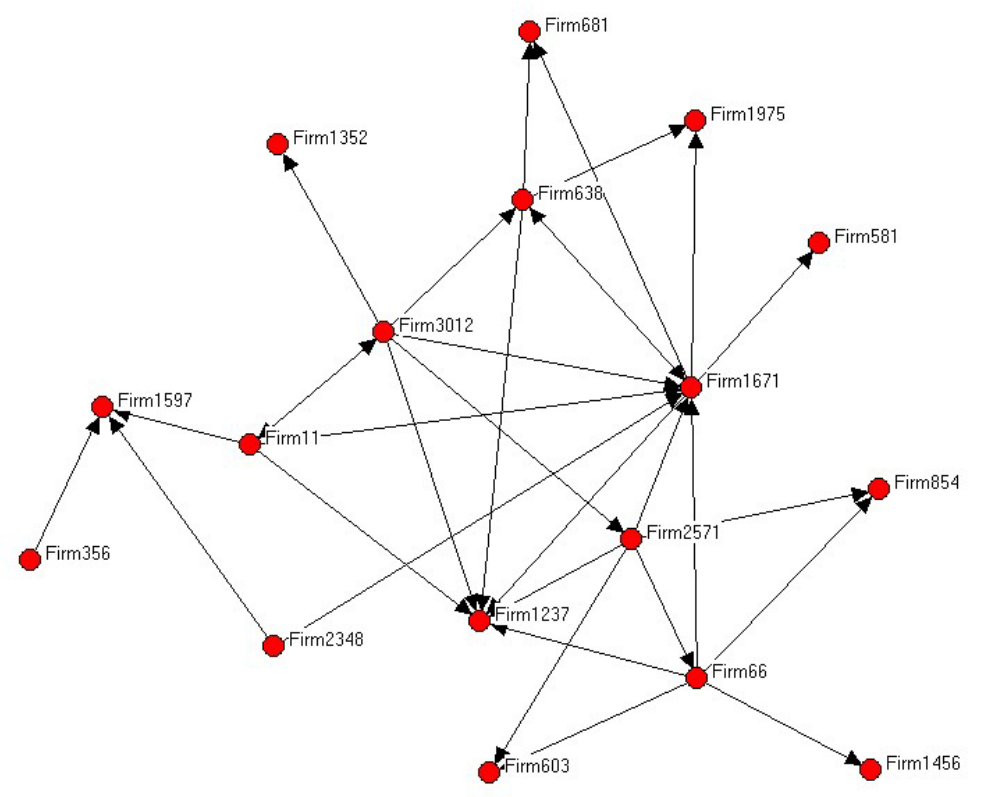

Figure 2. Example of a Sparsely Networked Market

The figure shows the network that arises from syndication of portfolio company investments in the market for nonhigh-tech ventures in Pennsylvania over the five-year window 1990-1994.

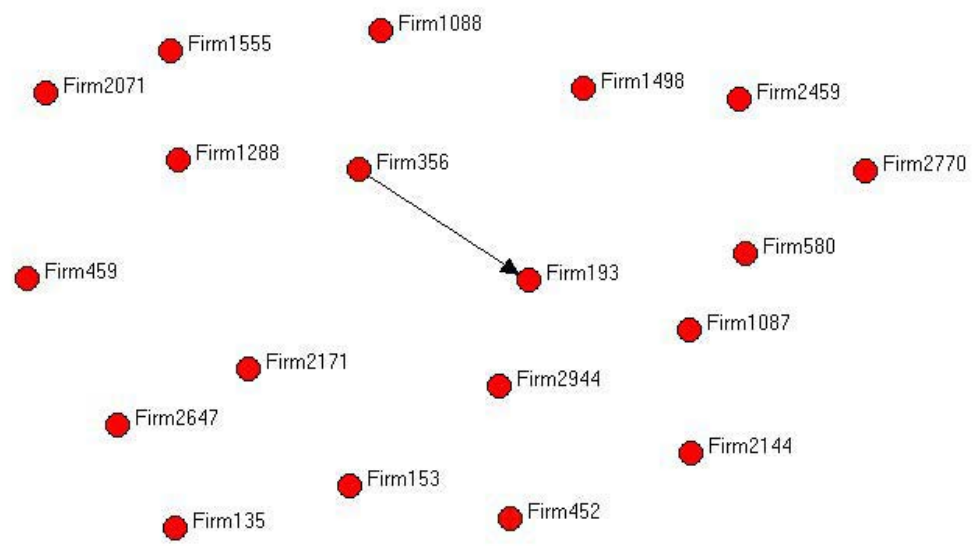




\section{Table I. Descriptive Sample Statistics.}

The unit of observation in this table is a market-year. We define a market as a combination of one of the six Venture Economics industries and either a U.S. state or a Metropolitan Statistical Area (MSA). Venture Economics classifies investments into the following industries: Biotechnology; communications and media; computer related; medical/health/life science; semiconductors/other electronics; and non-high-technology. To qualify for inclusion in the sample, a market-year has to have a minimum of 25 investments in the prior five years and five investments in the current year. There are 129 distinct state markets and 130 distinct MSA markets. Under each definition, there are between one and 24 annual observations for each market, resulting in 1,375 state-market-years and 1,292 MSAmarket-years. Entrants in Panel A are defined as VC firms investing in a given market in year $t$ that had never invested in this market before year $t$. For a market in year $t$, we use data from the previous five years (from $t-5$ to $t$ 1) to construct network densities, shown in Panel B. Density is defined as the proportion of all logically possible ties among incumbents that are present in the market. Asymmetric density is calculated from directed networks (i.e., conditioning on lead vs. syndicate participant ties) and symmetric density is calculated from undirected networks. Panel C characterizes the markets. To control for performance in a market, and in the absence of return data, we calculate the fraction of venture-backed firms in a market that were successfully exited through an IPO or an M\&A transaction during the prior five years. To measure excess performance in a market, we subtract from this the median exit rate across all geographic markets in the same Venture Economics industry. B/M is the value-weighted book/market ratio of public companies in the relevant industry. We map public-market $\mathrm{B} / \mathrm{M}$ ratios to industries based on four-digit SIC codes. The VC inflows variable is the real aggregate amount of capital raised by VC funds specializing in the industry. We take a fund's industry specialization to be the Venture Economics industry that accounts for the largest share of its portfolio, based on dollars invested. Potential entrants in Panel D are defined as the VC firms satisfying the following three conditions: (1) the firm was founded (i.e., raised its first fund) in or before year $t$; (2) the firm has at least one fund under management that was raised in the previous six years; and (3) the firm has not invested in this particular market prior to year $t$. We use trailing five-year windows to construct the characteristics of potential entrants. A potential entrant VC firm's indegree is the normalized number of unique VCs in the market in question that have led syndicates the firm was a non-lead member of. A potential entrant VC firm's outdegree is the normalized number of unique VCs in the market that have participated as non-lead investors in syndicates lead-managed by the firm. (The lead investor is identified as the VC firm that invests the largest amount in the portfolio company in a given round.) 
Table I. Descriptive Sample Statistics (Continued).

\begin{tabular}{|c|c|c|c|c|c|c|}
\hline & \multicolumn{3}{|c|}{ State markets } & \multicolumn{3}{|c|}{ MSA markets } \\
\hline & \multicolumn{3}{|c|}{ Std. } & \multicolumn{3}{|c|}{ Std. } \\
\hline \multicolumn{7}{|l|}{ Panel A: Entry measures } \\
\hline \# incumbents & 28.3 & 41.0 & 15 & 24.3 & 28.4 & 16 \\
\hline \# deals won by incumbents & 24.1 & 57.5 & 10 & 16.8 & 27.4 & 9 \\
\hline \# entrants & 14.7 & 19.9 & 9 & 12.7 & 17.0 & 8 \\
\hline \# entrants that lead syndicates & 7.2 & 9.6 & 5 & 5.8 & 7.8 & 4 \\
\hline $\begin{array}{l}\text { \# deals won by entrants } \\
\text { fraction of deals by \# lead-managed by }\end{array}$ & 8.5 & 12.2 & 5 & 6.7 & 9.6 & 4 \\
\hline entrants & 0.301 & 0.182 & 0.286 & 0.274 & 0.171 & 0.250 \\
\hline \multicolumn{7}{|l|}{ Panel B: Network measures } \\
\hline symmetric density & 0.078 & 0.052 & 0.067 & 0.092 & 0.053 & 0.081 \\
\hline \multicolumn{7}{|c|}{ Panel C: Market, state, and industry characteristics ( $t-1)$} \\
\hline excess investment performance in market & 0.047 & 0.095 & 0.038 & 0.151 & 0.108 & 0.140 \\
\hline coefficient of variation of monthly \# deals & 1.161 & 0.346 & 1.171 & 1.173 & 0.326 & 1.175 \\
\hline \# deals in market & 37.9 & 78.0 & 18 & 28.6 & 42.2 & 17 \\
\hline real GSP (\$billion) & 323.8 & 262.1 & 237.2 & 547.6 & 413.9 & 450.1 \\
\hline real GSP growth rate & 0.033 & 0.026 & 0.032 & 0.036 & 0.029 & 0.036 \\
\hline fraction of deals that are syndicated, $t-5$ to $t-1$ & 0.425 & 0.131 & 0.429 & 0.472 & 0.144 & 0.483 \\
\hline value-weighted mean industry $\mathrm{B} / \mathrm{M}$ ratio & 0.524 & 0.225 & 0.489 & 0.501 & 0.217 & 0.473 \\
\hline $\begin{array}{l}\text { inflow into VC funds in industry }(\$ \mathrm{~m}) \\
\text { \# science \& eng. degrees awarded in state per }\end{array}$ & $6,954.6$ & $12,309.6$ & $2,247.0$ & $7,415.4$ & $13,003.4$ & $2,247.0$ \\
\hline 1000 inhabitants & 2.6 & 0.8 & 2.5 & 2.5 & 0.5 & 2.4 \\
\hline $\begin{array}{l}\text { Panel D: Potential entrants } \\
\text { fraction located within } 100 \text { miles of market } \\
\text { fraction investing }\end{array}$ & 0.065 & 0.073 & 0.025 & 0.086 & 0.074 & 0.059 \\
\hline $\begin{array}{l}\text { in same industry and same area } \\
\text { fraction investing }\end{array}$ & 0.068 & 0.028 & 0.064 & 0.066 & 0.033 & 0.062 \\
\hline $\begin{array}{l}\text { in same industry but not same area } \\
\text { fraction investing }\end{array}$ & 0.310 & 0.157 & 0.291 & 0.318 & 0.153 & 0.298 \\
\hline in same area but not same industry & 0.059 & 0.081 & 0.028 & 0.044 & 0.046 & 0.025 \\
\hline fraction $\mathrm{w} /$ positive indegree & 0.200 & 0.096 & 0.193 & 0.206 & 0.090 & 0.203 \\
\hline fraction $\mathrm{w} /$ positive outdegree & 0.131 & 0.054 & 0.132 & 0.137 & 0.053 & 0.137 \\
\hline
\end{tabular}


Table II. Number of Deals Entrants Lead.

The dependent variable is the number of deals won by VC firms entering a market in year $t$. Given the count nature of the dependent variable, and the fact that we have repeated observations per market, we estimate conditional fixedeffects Poisson models. Intercepts are not shown. Heteroskedasticity-consistent standard errors (clustered on market) are shown in italics. We use ${ }^{* * * * *}$, and ${ }^{*}$ to denote significance at the $0.1 \%, 1 \%$, and $5 \%$ level, respectively. In the two specifications where markets are defined as state/industry pairs, the number of distinct markets is 129 and the number of observations (market-years) is 1,375. In the two specifications where markets are defined as MSA/industry pairs, the number of markets is 130 and the number of observations is 1,292.

\begin{tabular}{|c|c|c|c|c|}
\hline \multirow[b]{2}{*}{ Network measure used: } & \multicolumn{2}{|c|}{ State markets } & \multicolumn{2}{|c|}{ MSA markets } \\
\hline & $\begin{array}{c}\text { asymmetric } \\
\text { density }\end{array}$ & $\begin{array}{c}\text { symmetric } \\
\text { density }\end{array}$ & $\begin{array}{l}\text { asymmetric } \\
\text { density }\end{array}$ & $\begin{array}{c}\text { symmetric } \\
\text { density }\end{array}$ \\
\hline \multirow[t]{2}{*}{ network measure } & $-6.398^{* * *}$ & $-2.259^{* * *}$ & $-8.391^{* * *}$ & $-2.322^{* * *}$ \\
\hline & 1.945 & 0.469 & 1.933 & 0.416 \\
\hline \multicolumn{5}{|l|}{ Potential entrants } \\
\hline \multirow[t]{2}{*}{ fraction headquartered within 100 miles } & $1.605^{* * *}$ & $1.567^{* * *}$ & $0.656^{* *}$ & $0.644^{* *}$ \\
\hline & 0.338 & 0.338 & 0.212 & 0.212 \\
\hline \multirow[t]{2}{*}{ fraction investing in same industry and same area } & $1.794^{*}$ & $1.856^{*}$ & $2.839^{* * *}$ & $2.994^{* * *}$ \\
\hline & 0.853 & 0.851 & 0.602 & 0.602 \\
\hline \multirow[t]{2}{*}{ fraction investing in same industry but not in area } & $0.680^{*}$ & $0.633^{*}$ & $-0.582^{* * *}$ & $-0.579^{* * *}$ \\
\hline & 0.270 & 0.270 & 0.171 & 0.171 \\
\hline \multirow[t]{2}{*}{ fraction investing in same area but not in industry } & $-2.117^{* * *}$ & $-2.142^{* * *}$ & $-1.715^{* * *}$ & $-1.693^{* *}$ \\
\hline & 0.559 & 0.560 & 0.539 & 0.538 \\
\hline \multirow[t]{2}{*}{ fraction $\mathrm{w} /$ positive indegree } & 0.074 & 0.080 & -0.817 & -0.733 \\
\hline & 0.451 & 0.451 & 0.474 & 0.474 \\
\hline \multirow[t]{2}{*}{ fraction $\mathrm{w} /$ positive outdegree } & $2.163^{* *}$ & $2.179^{* *}$ & $4.357^{* * *}$ & $4.123^{* * *}$ \\
\hline & 0.723 & 0.723 & 0.756 & 0.757 \\
\hline \multicolumn{5}{|l|}{ Market, state, and industry characteristics $(t-1)$} \\
\hline \multirow[t]{2}{*}{ fraction of deals syndicated, $t-5$ to $t-1$} & 0.301 & 0.289 & $-0.571^{* * *}$ & $-0.585^{* * *}$ \\
\hline & 0.177 & 0.174 & 0.149 & 0.140 \\
\hline \multirow[t]{2}{*}{ 1/(\# distinct VC firms incumbent in the market) } & 0.832 & -0.148 & 1.278 & -0.931 \\
\hline & 1.508 & 1.377 & 1.986 & 1.689 \\
\hline \multirow[t]{2}{*}{ excess investment performance in market } & 0.180 & 0.190 & -0.139 & -0.135 \\
\hline & 0.163 & 0.164 & 0.138 & 0.138 \\
\hline \multirow[t]{2}{*}{ value-weighted mean industry book/market ratio } & $-2.149^{* * *}$ & $-2.131^{* * *}$ & $-0.789^{* * *}$ & $-0.877^{* * *}$ \\
\hline & 0.179 & 0.179 & 0.114 & 0.117 \\
\hline \multirow[t]{2}{*}{ coeff. variation of monthly no. of deals in market } & $0.138^{*}$ & $0.139^{*}$ & 0.049 & 0.051 \\
\hline & 0.062 & 0.061 & 0.062 & 0.062 \\
\hline \multirow[t]{2}{*}{$\log$ inflow into VC funds in industry (\$m) } & $0.147^{* * *}$ & $0.147^{* * *}$ & $0.245^{* * *}$ & $0.240^{* * *}$ \\
\hline & 0.025 & 0.025 & 0.017 & 0.017 \\
\hline \multirow[t]{2}{*}{ log no. deals in market } & 0.058 & 0.045 & $0.421^{* * *}$ & $0.404^{* * *}$ \\
\hline & 0.037 & 0.037 & 0.025 & 0.026 \\
\hline \multirow[t]{2}{*}{ \# science \& engineering degrees awarded/1000 inhabitants } & 0.051 & 0.056 & $-0.092^{* *}$ & $-0.085^{*}$ \\
\hline & 0.048 & 0.048 & 0.035 & 0.035 \\
\hline \multirow[t]{2}{*}{$\log$ real GSP $(\$ m)$} & $-0.998^{* * *}$ & $-1.034^{* * *}$ & $-0.037^{*}$ & $-0.036^{*}$ \\
\hline & 0.254 & 0.256 & 0.017 & 0.017 \\
\hline \multirow[t]{2}{*}{ real GSP growth rate (\%) } & 0.868 & 0.852 & -0.151 & -0.194 \\
\hline & 0.633 & 0.632 & 0.616 & 0.616 \\
\hline \multicolumn{5}{|l|}{ Diagnostics } \\
\hline Pseudo- $R^{2}$ & $59.1 \%$ & $59.2 \%$ & $53.2 \%$ & $53.3 \%$ \\
\hline Wald-test: all coeff. $=0\left(\chi^{2}\right)$ & $10,249^{* * *}$ & $10,262^{* * *}$ & $7,420.4^{* * *}$ & $7,433.3^{* * *}$ \\
\hline
\end{tabular}


Table III. First-stage Models.

The models are estimated using OLS with fixed (market) effects. The motivation for our two instruments can be found in the text. All control variables are defined as in Table I. Intercepts are not shown. Heteroskedasticityconsistent standard errors (clustered on market) are shown in italics. We use ${ }^{* * *},{ }^{* *}$, and ${ }^{*}$ to denote significance at the $0.1 \%, 1 \%$, and $5 \%$ level (two-sided), respectively. In the two specifications where markets are defined as state/industry pairs, the number of distinct markets is 129 and the number of observations (market-years) is 1,375 . In the two specifications where markets are defined as MSA/industry pairs, the number of markets is 130 and the number of observations is 1,292 .

\begin{tabular}{|c|c|c|c|c|}
\hline \multirow[b]{2}{*}{ Dependent variable: } & \multicolumn{2}{|c|}{ State markets } & \multicolumn{2}{|c|}{ MSA markets } \\
\hline & $\begin{array}{c}\text { asymmetric } \\
\text { density }\end{array}$ & $\begin{array}{c}\text { symmetric } \\
\text { density }\end{array}$ & $\begin{array}{c}\text { asymmetric } \\
\text { density }\end{array}$ & $\begin{array}{c}\text { symmetric } \\
\text { density }\end{array}$ \\
\hline \multicolumn{5}{|l|}{ Instruments } \\
\hline \multirow{2}{*}{ entropy of demand distribution } & $-0.002^{*}$ & $-0.017^{* * *}$ & $-0.002^{* * *}$ & $-0.022^{* * *}$ \\
\hline & 0.001 & 0.004 & 0.001 & 0.003 \\
\hline \multirow[t]{2}{*}{ fraction of $\$$ invested by corporate VCs in market } & $-0.020^{* * *}$ & $-0.086^{* * *}$ & $-0.007^{*}$ & -0.020 \\
\hline & 0.004 & 0.015 & 0.003 & 0.014 \\
\hline \multicolumn{5}{|l|}{ Potential entrants } \\
\hline \multirow[t]{2}{*}{ fraction headquartered within 100 miles } & 0.013 & 0.044 & -0.008 & -0.042 \\
\hline & 0.007 & 0.031 & 0.009 & 0.040 \\
\hline \multirow[t]{2}{*}{ fraction having invested in same industry and same area } & $-0.045^{* *}$ & -0.046 & $0.030^{*}$ & $0.205^{* * *}$ \\
\hline & 0.015 & 0.066 & 0.014 & 0.061 \\
\hline \multirow[t]{2}{*}{ fraction having invested in same industry but not in area } & $-0.019^{* * *}$ & $-0.063^{* * *}$ & 0.000 & -0.015 \\
\hline & 0.005 & 0.020 & 0.004 & 0.018 \\
\hline \multirow[t]{2}{*}{ fraction having invested in same area but not in industry } & -0.012 & -0.037 & -0.002 & -0.080 \\
\hline & 0.011 & 0.049 & 0.014 & 0.063 \\
\hline \multirow[t]{2}{*}{ fraction $\mathrm{w} /$ positive indegree } & -0.005 & -0.024 & $-0.018^{*}$ & -0.057 \\
\hline & 0.008 & 0.036 & 0.008 & 0.036 \\
\hline \multirow[t]{2}{*}{ fraction $\mathrm{w} /$ positive outdegree } & 0.004 & 0.040 & 0.010 & 0.018 \\
\hline & 0.014 & 0.059 & 0.013 & 0.058 \\
\hline
\end{tabular}

Continued over. 
Table III. First-stage Models (Continued).

\begin{tabular}{|c|c|c|c|c|}
\hline \multirow[b]{2}{*}{ Dependent variable: } & \multicolumn{2}{|c|}{ State markets } & \multicolumn{2}{|c|}{ MSA markets } \\
\hline & $\begin{array}{c}\text { asymmetric } \\
\text { density }\end{array}$ & $\begin{array}{c}\text { symmetric } \\
\text { density }\end{array}$ & $\begin{array}{c}\text { asymmetric } \\
\text { density }\end{array}$ & $\begin{array}{c}\text { symmetri } \\
\text { density }\end{array}$ \\
\hline \multicolumn{5}{|l|}{ Market, state, and industry characteristics $(t-1)$} \\
\hline \multirow[t]{2}{*}{ fraction of deals syndicated, $t-5$ to $t-1$} & $0.029^{* * *}$ & $0.067^{* * *}$ & $0.040^{* * *}$ & $0.105^{* * *}$ \\
\hline & 0.003 & 0.013 & 0.002 & 0.011 \\
\hline \multirow[t]{2}{*}{$1 /(\#$ distinct VC firms incumbent in the market) } & $0.326^{* * *}$ & 0.190 & $0.598^{* * *}$ & $0.856^{* * *}$ \\
\hline & 0.025 & 0.110 & 0.027 & 0.123 \\
\hline \multirow[t]{2}{*}{ excess investment performance in market } & 0.002 & 0.020 & 0.000 & -0.005 \\
\hline & 0.003 & 0.011 & 0.002 & 0.010 \\
\hline \multirow[t]{2}{*}{ value-weighted mean industry book/market ratio } & 0.002 & 0.024 & 0.003 & 0.000 \\
\hline & 0.003 & 0.014 & 0.003 & 0.014 \\
\hline \multirow[t]{2}{*}{ coeff. of variation of monthly no. of deals in market } & $-0.004^{* *}$ & -0.005 & $-0.004^{* * *}$ & $-0.019^{* * *}$ \\
\hline & 0.001 & 0.005 & 0.001 & 0.005 \\
\hline \multirow[t]{2}{*}{$\log$ inflow into VC funds in industry (\$m) } & 0.000 & -0.002 & 0.000 & -0.002 \\
\hline & 0.000 & 0.002 & 0.000 & 0.002 \\
\hline \multirow[t]{2}{*}{$\log$ no. deals in market } & 0.000 & -0.003 & 0.000 & $-0.006^{*}$ \\
\hline & 0.001 & 0.003 & 0.001 & 0.003 \\
\hline \multirow[t]{2}{*}{ \# science \& engineering degrees awarded/1000 inhabitants } & $-0.003^{* * *}$ & -0.007 & $-0.004^{* *}$ & -0.009 \\
\hline & 0.001 & 0.004 & 0.001 & 0.006 \\
\hline \multirow[t]{2}{*}{$\log$ real GSP $(\$ m)$} & $-0.015^{* * *}$ & $-0.069^{* * *}$ & -0.001 & 0.004 \\
\hline & 0.004 & 0.018 & 0.002 & 0.009 \\
\hline \multirow[t]{2}{*}{ real GSP growth rate $(\%)$} & $0.031^{* *}$ & 0.074 & 0.002 & -0.045 \\
\hline & 0.011 & 0.049 & 0.010 & 0.044 \\
\hline \multicolumn{5}{|l|}{ Diagnostics } \\
\hline Within-groups $R^{2}$ & $60.3 \%$ & $54.3 \%$ & $68.8 \%$ & $60.7 \%$ \\
\hline Wald-test: all coeff. $=0(F)$ & $44.5^{* * *}$ & $34.8^{* * *}$ & $61.8^{* * *}$ & $43.3^{* * *}$ \\
\hline$F$-test: all $\mathrm{FE}=0$ & $5.5^{* * *}$ & $5.9^{* * *}$ & $7.1^{* * *}$ & $7.2^{* * *}$ \\
\hline Instrument strength test ( $F$-test with critical value of 10$)$ & $17.8^{* * *}$ & $24.4^{* * *}$ & $7.5^{* * *}$ & $20.4^{* * *}$ \\
\hline
\end{tabular}




\section{Table IV. Entry Models using Two-stage Estimators.}

The table reports the results of two-stage (instrumental variables) entry models similar to the single-stage entry models shown in Table II. We treat the network measures as endogenous and replace them with the predicted values generated from the regressions shown in Table III. The dependent variables in Panels A, B, and C are the number of deals won by $\mathrm{VC}$ firms entering a market in year $t$, the number of $\mathrm{VC}$ firms entering a market in year $t$, and the number of $\mathrm{VC}$ firms entering a market that lead-manage syndicates in year $t$, respectively. Given the count nature of these dependent variables, and the fact that we have repeated observations per market, the models in Panels A-C are estimated using conditional fixed-effects Poisson. The dependent variable in Panel D is the fraction of deals by number lead-managed by entrants in a market in year $t$. This dependent variable has support on $[0,1]$ and positive mass at both 0 and 1 . To avoid the resulting well-known biases of OLS in this situation, we estimate fractional logit models using quasi-MLE; see Papke and Wooldridge (1996). This involves modeling the conditional mean $\mathrm{E}(\mathrm{y} \mid \mathrm{x})=\exp (\mathrm{x} \beta) /(1+\exp (\mathrm{x} \beta))$. Note that fractional logits cannot currently accommodate fixed effects. Thus, we pool repeated observations on each market in Panel D. To save space, we report only the coefficient estimates for the network measures; the coefficient estimates for the controls mirror those shown in Table II. Standard errors, shown in italics, are based on the Murphy-Topel (1985) adjustment. We use ${ }^{* * *},{ }^{* *}$, and ${ }^{*}$ to denote significance at the $0.1 \%$, $1 \%$, and $5 \%$ level (two-sided), respectively. In the specifications where markets are defined as state/industry pairs, the number of distinct markets is 129 and the number of observations (market-years) is 1,375. In the specifications where markets are defined as MSA/industry pairs, the number of markets is 130 and the number of observations is 1,292 .

\begin{tabular}{|c|c|c|c|c|}
\hline \multirow[b]{2}{*}{ Network measure used: } & \multicolumn{2}{|c|}{ State markets } & \multicolumn{2}{|c|}{ MSA markets } \\
\hline & $\begin{array}{l}\text { asymmetric } \\
\text { density }\end{array}$ & $\begin{array}{c}\text { symmetric } \\
\text { density }\end{array}$ & $\begin{array}{l}\text { asymmetric } \\
\text { density }\end{array}$ & $\begin{array}{c}\text { symmetric } \\
\text { density }\end{array}$ \\
\hline
\end{tabular}

\section{Panel A: Number of deals entrants lead}

instrumented network measure

$\begin{array}{cccc}-23.222^{* *} & -4.580^{*} & -9.041^{* *} & -3.136^{* * *} \\ 8.863 & 2.092 & 3.429 & 0.722 \\ & & & \\ 59.3 \% & 59.3 \% & 52.7 \% & 52.9 \%\end{array}$

Pseudo- $R^{2}$

Panel B: Number of entrants

instrumented network measure

$\begin{array}{cccc}-26.732^{* * *} & -5.462^{* *} & -11.508^{* * *} & -1.580^{* * *} \\ 6.454 & 2.099 & 2.857 & 0.489 \\ & & & \\ 69.2 \% & 69.2 \% & 63.4 \% & 63.4 \%\end{array}$

Pseudo- $R^{2}$

\section{Panel C: Number of entrants leading syndicates}

instrumented network measure

$\begin{array}{rrrr}-23.167^{*} & -4.614^{*} & -7.370^{*} & -2.618^{* * *} \\ 9.385 & 2.084 & 3.468 & 0.688 \\ & & & \\ 55.7 \% & 55.7 \% & 49.8 \% & 49.9 \%\end{array}$

Pseudo- $R^{2}$

$55.7 \%$

\section{Panel D: Fraction of deals entrants lead}

instrumented network measure

$\begin{array}{cccc}-13.800^{* * *} & -3.546^{* * *} & -12.895^{* *} & -3.001^{* * *} \\ 3.787 & 0.906 & 4.304 & 0.901 \\ 48.9 \% & 49.0 \% & 35.7 \% & 35.7 \%\end{array}$

$R^{2}$

$48.9 \%$ 
Table V. Entry Models with Correction for Omitted Variables.

The table reports the results of entry models purged of the effects of omitted variables that are time-varying and either location-specific $\left(C_{l t}\right)$ or industry-specific $\left(C_{s t}\right)$ and that simultaneously affect networking decisions and entry. The omitted variable correction exploits the nested panel structure of our data. It consists of augmenting the entry models with proxies for $C_{l t}$ and $C_{s t}$, constructed as $\operatorname{density}_{l s t}$ - mean(density $\left.{ }_{l s t}\right)$ - [predicted density ${ }_{l s t}-$ mean(predicted density $\left.\left.{ }_{l s t}\right)\right]$. To obtain a proxy for $C_{l t}$, means are computed across locations $l$ and within year $t$ and industry $s$; for $C_{s}$, means are computed across industries $s$ and within year $t$ and location $l$. Predicted densities are obtained from the models shown in Table III, without instruments. The inclusion of $C_{l t}$ and $C_{s t}$ in the entry model removes the effect of the omitted variables from the coefficients estimated for the networking variables, our primary variables of interest. The dependent variables and econometric specifications are the same as for the entry models shown in Table IV. To save space, we report only the coefficient estimates for the network measures; the coefficient estimates for the controls mirror those shown in Table II. Standard errors are shown in italics. We use ${ }^{* * *},{ }^{* *}$, and ${ }^{*}$ to denote significance at the $0.1 \%, 1 \%$, and $5 \%$ level (two-sided), respectively. In the specifications where markets are defined as state/industry pairs, the number of distinct markets is 129 and the number of observations (market-years) is 1,375 . In the specifications where markets are defined as MSA/industry pairs, the number of markets is 130 and the number of observations is 1,292 .

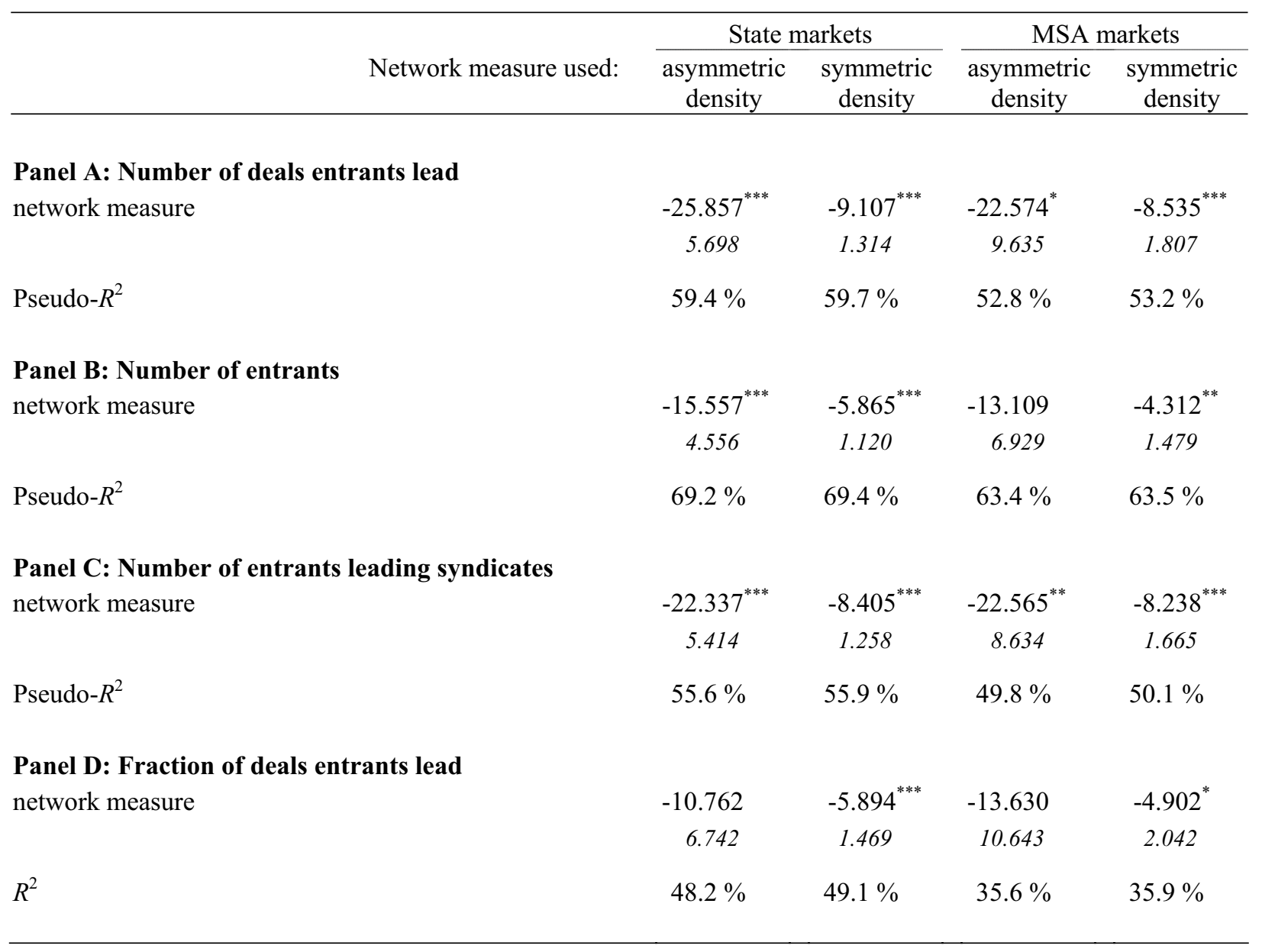


Table VI. Entry Levels and Rates.

In this table, we define a market as a combination of one of the six Venture Economics industries and a U.S. state. (Results for markets defined as MSA/industry pairs are similar and not shown.) Venture Economics classifies investments into the following industries: Biotechnology; communications and media; computer related; medical/health/life science; semiconductors/other electronics; and non-high-technology. To qualify for inclusion in the sample, a market has to have a minimum of 25 investments in the prior five years and five investments in the current year. There are 129 markets with between one and 24 annual observations, giving a total number of observations of 1,375. Potential entrants are defined as U.S. VC firms that have never invested in a given market prior to year $t$. Entrants are defined as potential entrants that invest in the market in year $t$. The fractions of potential entrants that enter in the final column are pairwise significantly different at the $0.1 \%$ level for each question in the table.

Total \# of potential entrants

\# entering

$\%$ entering

Panel A: Prior syndication ties to incumbents

Has potential entrant participated in deals led by incumbents in prior 5 years? (positive indegree)
Yes
260,399
8,786
3.37
No
$1,186,769$
11,690
0.99

Has potential entrant led deals with incumbents as co-investors in prior 5 years? (positive outdegree)
Yes
170,659
6,483
3.80
No
$1,276,509$
13,993
1.10

Panel B: Proximity to target market

Is the potential entrant located within 100 miles of the center of the target market?
Yes
74,963
3,757
5.01
No
$1,215,246$
15,499
1.28

Panel C: Prior investment experience

Has potential entrant invested in the same industry and same state in prior 5 years (but not in this market)?
Yes
91,891
4,061
4.42
No
$1,355,277$
16,415
1.21

Has potential entrant invested in the same state but not the same industry in prior 5 years?
Yes
81,409
2,245
2.76
No
$1,365,759$
18,231
1.33

Has potential entrant invested in the same industry but not the same state in prior 5 years?
Yes
484,014
7,180
1.48
No
963,154
13,296
1.38 
Table VII. Firm-level Entry Models: Syndicate Membership.

The dependent variable equals one if the potential entrant enters, and zero otherwise. Where markets are defined as state/industry pairs, there are 1,131 market-years and 3,024 distinct potential entrants. Where markets are defined as MSA/industry pairs, there are 970 market-years and 2,993 distinct potential entrants. All models are estimated using probit MLE. Intercepts and year fixed effects are not shown. Heteroskedasticity-consistent standard errors are shown in italics. We use ${ }^{* * *},{ }^{* *}$, and ${ }^{*}$ to denote significance at the $0.1 \%, 1 \%$, and $5 \%$ level (two-sided), respectively.

\begin{tabular}{|c|c|c|c|c|}
\hline \multirow[b]{2}{*}{ Network measure used: } & \multicolumn{2}{|c|}{ State markets } & \multicolumn{2}{|c|}{ MSA markets } \\
\hline & $\begin{array}{c}\text { asymmetric } \\
\text { density }\end{array}$ & $\begin{array}{c}\text { symmetric } \\
\text { density }\end{array}$ & $\begin{array}{c}\text { asymmetric } \\
\text { density }\end{array}$ & $\begin{array}{c}\text { symmetric } \\
\text { density }\end{array}$ \\
\hline \multirow[t]{2}{*}{ network measure } & $-1.748^{* * *}$ & $-0.493^{* * *}$ & $-1.472^{* * *}$ & $-0.368^{* *}$ \\
\hline & 0.482 & 0.122 & 0.454 & 0.121 \\
\hline \multicolumn{5}{|l|}{ Potential entrants } \\
\hline \multirow[t]{2}{*}{$=1$ if positive outdegree } & $0.037^{*}$ & $0.041^{* *}$ & $0.110^{* * *}$ & $0.111^{* * *}$ \\
\hline & 0.015 & 0.015 & 0.017 & 0.017 \\
\hline \multirow[t]{2}{*}{$\ldots \mathrm{x}$ network measure } & $3.276^{* * *}$ & $0.794^{* * *}$ & 1.149 & 0.289 \\
\hline & 0.703 & 0.180 & 0.709 & 0.179 \\
\hline \multirow[t]{2}{*}{$=1$ if positive indegree } & $0.065^{* * *}$ & $0.064^{* * *}$ & $0.077^{* * *}$ & $0.070^{* * *}$ \\
\hline & 0.014 & 0.014 & 0.016 & 0.016 \\
\hline \multirow[t]{2}{*}{$\ldots \mathrm{x}$ network measure } & $3.207^{* * *}$ & $0.846^{* * *}$ & $3.401^{* * *}$ & $0.953^{* * *}$ \\
\hline & 0.669 & 0.170 & 0.669 & 0.169 \\
\hline \multirow[t]{2}{*}{$\ln (1+$ assets under management since VC firm's inception) } & $0.069^{* * *}$ & $0.069^{* * *}$ & $0.050^{* * *}$ & $0.050^{* * *}$ \\
\hline & 0.002 & 0.002 & 0.002 & 0.002 \\
\hline \multirow[t]{2}{*}{$=1$ if located within 100 miles of center of market } & $0.530^{* * *}$ & $0.530^{* * *}$ & $0.582^{* * *}$ & $0.582^{* * *}$ \\
\hline & 0.009 & 0.009 & 0.009 & 0.009 \\
\hline \multirow[t]{2}{*}{$=1$ if has invested in same industry and same area $(-5 \mathrm{yrs})$} & $0.390^{* * *}$ & $0.389^{* * *}$ & $0.488^{* * *}$ & $0.486^{* * *}$ \\
\hline & 0.011 & 0.011 & 0.012 & 0.012 \\
\hline \multirow[t]{2}{*}{$=1$ if has invested in same industry but not in area $(-5 \mathrm{yrs})$} & $0.181^{* * *}$ & $0.181^{* * *}$ & $0.228^{* * *}$ & $0.228^{* * *}$ \\
\hline & 0.008 & 0.008 & 0.009 & 0.009 \\
\hline \multirow[t]{2}{*}{$=1$ if has invested in same area but not in industry $(-5 \mathrm{yrs})$} & $0.131^{* * *}$ & $0.130^{* * *}$ & $0.119^{* * *}$ & $0.118^{* * *}$ \\
\hline & 0.013 & 0.013 & 0.016 & 0.016 \\
\hline
\end{tabular}

Continued over. 
Table VII. Firm-level Entry Models: Syndicate Membership (Continued).

\begin{tabular}{|c|c|c|c|c|}
\hline \multirow[b]{2}{*}{ Network measure used: } & \multicolumn{2}{|c|}{ State markets } & \multicolumn{2}{|c|}{ MSA markets } \\
\hline & $\begin{array}{l}\text { asymmetric } \\
\text { density }\end{array}$ & $\begin{array}{c}\text { symmetric } \\
\text { density }\end{array}$ & $\begin{array}{l}\text { asymmetric } \\
\text { density }\end{array}$ & $\begin{array}{c}\text { symmetric } \\
\text { density }\end{array}$ \\
\hline \multicolumn{5}{|l|}{ Market, state, and industry characteristics $(t-1)$} \\
\hline \multirow[t]{2}{*}{ excess investment performance in market } & 0.065 & 0.061 & 0.068 & 0.068 \\
\hline & 0.039 & 0.039 & 0.039 & 0.039 \\
\hline \multirow[t]{2}{*}{ value-weighted mean industry book/market ratio } & $-0.329^{* * *}$ & $-0.333^{* * *}$ & $-0.309^{* * *}$ & $-0.302^{* * *}$ \\
\hline & 0.023 & 0.024 & 0.027 & 0.028 \\
\hline \multirow[t]{2}{*}{ coeff. variation of monthly no. of deals in market } & $0.156^{* * *}$ & $0.156^{* * *}$ & $0.138^{* * *}$ & $0.138^{* * *}$ \\
\hline & 0.015 & 0.015 & 0.016 & 0.015 \\
\hline \multirow[t]{2}{*}{$\log$ inflow into VC funds in industry $(\$ \mathrm{~m})$} & $0.037^{* * *}$ & $0.037^{* * *}$ & $0.031^{* * *}$ & $0.032^{* * *}$ \\
\hline & 0.004 & 0.004 & 0.004 & 0.004 \\
\hline \multirow[t]{2}{*}{$\log$ no. deals in market } & $0.347^{* * *}$ & $0.346^{* * *}$ & $0.340^{* * *}$ & $0.342^{* * *}$ \\
\hline & 0.006 & 0.006 & 0.006 & 0.007 \\
\hline \multirow[t]{2}{*}{$\log$ real GSP $(\$ m)$} & -0.003 & -0.003 & 0.002 & 0.002 \\
\hline & 0.005 & 0.005 & 0.003 & 0.003 \\
\hline \multirow[t]{2}{*}{ real GSP growth rate } & $0.518^{* *}$ & $0.533^{* *}$ & $0.404^{*}$ & $0.416^{*}$ \\
\hline & 0.181 & 0.181 & 0.174 & 0.174 \\
\hline \multicolumn{5}{|l|}{ Diagnostics } \\
\hline Pseudo- $R^{2}$ & $15.8 \%$ & $15.8 \%$ & $16.2 \%$ & $16.2 \%$ \\
\hline Wald test: all coeff. $=0\left(\chi^{2}\right)$ & $26,945^{* * *}$ & $26,990^{* * *}$ & $22,858^{* * *}$ & $22,893^{* * *}$ \\
\hline Wald test: network measure $\cdot(1+$ outdegree $)=0$ & $4.0^{*}$ & 2.3 & 0.2 & 0.2 \\
\hline Wald test: network measure $\cdot(1+$ indegree $)=0$ & $4.5^{*}$ & $4.0^{*}$ & $8.1^{* *}$ & $11.5^{* * *}$ \\
\hline Wald test: network measure $\cdot(1+$ indegree + outdegree $)=0$ & $65.6^{* * *}$ & $58.9^{* * *}$ & $27.1^{* * *}$ & $33.2^{* * *}$ \\
\hline
\end{tabular}


Table VIII. Incumbents' Reaction to an Increased Threat of Entry.

The unit of observation is an incumbent $\mathrm{VC}$ firm, $i$. The dependent variable is the change in the probability that an incumbent $\mathrm{VC}$ firm $i$ is invited to join a syndicate lead-managed by another incumbent operating in the same market. The main variable of interest is an indicator set equal to one if $\mathrm{VC}$ firm $i$ co-syndicated with a potential entrant in another market during year $t$ - 1 . This raises the probability of entry in the home market. The table tests the hypothesis that the other incumbents in the home market react by punishing VC firm $i$ by excluding it from some or all of their syndicates for a period of time. We expect the likelihood and severity of punishment to be greater the fewer incumbents are active in the market. We compute the change in syndication probability from year $t$ to each of the next five years as the fraction of rounds lead-managed by the other incumbents that the incumbent VC firm $i$ participates in. Note that VC firms entering after year $t$ (i.e., future incumbents) are not included in this calculation, as they cannot plausibly punish VC firm $i$. We screen out markets with a monopolist incumbent. The estimation sample size drops over the five years due to attrition as some of the original incumbents reach the end of their economic lives. All regressions are estimated using OLS. Intercepts, year effects, and industry effects are included but not reported. Heteroskedasticity-consistent standard errors are shown in italics. We use ${ }^{* * *},{ }^{* *}$, and ${ }^{*}$ to denote significance at the $0.1 \%, 1 \%$, and $5 \%$ level (two-sided), respectively.

\begin{tabular}{|c|c|c|c|c|c|}
\hline & \multicolumn{5}{|c|}{ Change in $\operatorname{Pr}$ (invited into syndicate), in \%, through } \\
\hline & $t+1$ & $t+2$ & $t+3$ & $t+4$ & $t+5$ \\
\hline \multicolumn{6}{|l|}{ Panel A: State markets } \\
\hline \multirow{2}{*}{$=1$ if syndicated with potential entrant } & -0.313 & -0.455 & -0.253 & -0.504 & -0.058 \\
\hline & 0.275 & 0.258 & 0.309 & 0.323 & 0.346 \\
\hline \multirow{2}{*}{$\ldots \times$ ( 5 or fewer incumbents $)$} & -0.806 & $-1.843^{* *}$ & $-3.263^{* * *}$ & $-2.864^{* *}$ & $-4.283^{* * *}$ \\
\hline & 0.744 & 0.724 & 0.853 & 0.910 & 1.004 \\
\hline \multirow[t]{2}{*}{ VC firm's size (\$ under mgmt.) } & $0.283^{* *}$ & $0.461^{* * *}$ & $0.550^{* * *}$ & $0.631^{* * *}$ & $0.728^{* * *}$ \\
\hline & 0.101 & 0.098 & 0.119 & 0.137 & 0.133 \\
\hline \multirow[t]{2}{*}{ VC firm's degree } & -0.015 & $-0.071^{* * *}$ & $-0.076^{* *}$ & $-0.097^{* * *}$ & $-0.128^{* * *}$ \\
\hline & 0.022 & 0.021 & 0.024 & 0.025 & 0.023 \\
\hline Wald test: all coeff. $=0(F)$ & $2.4^{* * *}$ & $5.2^{* * *}$ & $5.0^{* * *}$ & $5.9^{* * *}$ & $5.7^{* * *}$ \\
\hline Adjusted $R^{2}$ & $0.5 \%$ & $1.2 \%$ & $1.4 \%$ & $1.5 \%$ & $2.5 \%$ \\
\hline No. of observations & 12,619 & 11,361 & 9,913 & 8,293 & 7,228 \\
\hline \multicolumn{6}{|l|}{ Panel B: MSA markets } \\
\hline \multirow[t]{2}{*}{$=1$ if syndicated with potential entrant } & -0.481 & -0.360 & -0.617 & -0.735 & 0.013 \\
\hline & 0.400 & 0.450 & 0.435 & 0.543 & 0.592 \\
\hline \multirow[t]{2}{*}{$\ldots \times$ ( 5 or fewer incumbents $)$} & $-1.747^{*}$ & -0.502 & $-2.942^{* * *}$ & $-3.816^{* * *}$ & $-2.912^{* *}$ \\
\hline & 0.722 & 0.796 & 0.859 & 0.928 & 0.944 \\
\hline \multirow[t]{2}{*}{ VC firm's size ( $\$$ under mgmt.) } & $0.698^{* * *}$ & $0.679^{* * *}$ & $0.932^{* * *}$ & $1.111^{* * *}$ & $1.200^{* * *}$ \\
\hline & 0.122 & 0.136 & 0.145 & 0.170 & 0.181 \\
\hline \multirow[t]{2}{*}{ VC firm's degree } & $-0.093^{* * *}$ & $-0.086^{* *}$ & $-0.120^{* * *}$ & $-0.157^{* * *}$ & $-0.206^{* * *}$ \\
\hline & 0.026 & 0.028 & 0.028 & 0.031 & 0.031 \\
\hline Wald test: all coeff. $=0(F)$ & $3.7^{* * *}$ & $5.0^{* * *}$ & $6.8^{* * *}$ & $6.6^{* * *}$ & $6.7^{* * *}$ \\
\hline Adjusted $R^{2}$ & $1.0 \%$ & $1.0 \%$ & $2.2 \%$ & $2.5 \%$ & $2.4 \%$ \\
\hline No. of observations & 11,348 & 10,053 & 8,475 & 6,960 & 5,878 \\
\hline
\end{tabular}


Table IX. Round-level Valuation Models.

The unit of observation is a funding round and the dependent variable is the log of the valuation put on the company in that round. All models are estimated using OLS with market fixed effects. Markets are defined either as state/industry pairs or as MSA/industry pairs. In the latter definition, we lose some observations due to missing zip codes. Year effects are jointly and individually insignificant and so excluded. Intercepts are not shown. Standard errors are shown in italics. We use ${ }^{* * *},{ }^{* *}$, and ${ }^{*}$ to denote significance at the $0.1 \%, 1 \%$, and $5 \%$ level (two-sided), respectively.

\begin{tabular}{|c|c|c|c|c|}
\hline \multirow[b]{3}{*}{ Network measure used: } & \multicolumn{4}{|c|}{ Dependent variable: $\log$ valuation } \\
\hline & \multicolumn{2}{|c|}{ State markets } & \multicolumn{2}{|c|}{ MSA markets } \\
\hline & $\begin{array}{c}\text { asymmetric } \\
\text { density }\end{array}$ & $\begin{array}{c}\text { symmetric } \\
\text { density }\end{array}$ & $\begin{array}{c}\text { asymmetric } \\
\text { density }\end{array}$ & $\begin{array}{c}\text { symmetric } \\
\text { density }\end{array}$ \\
\hline \multirow[t]{2}{*}{ network measure } & $-12.503^{* * *}$ & $-3.898^{* * *}$ & $-10.657^{* * *}$ & $-4.227^{* * *}$ \\
\hline & 2.361 & 0.685 & 2.135 & 0.682 \\
\hline \multirow[t]{2}{*}{ fraction of deals won by entrants in previous year } & $0.616^{* * *}$ & $0.648^{* * *}$ & $0.353^{* *}$ & $0.385^{* * *}$ \\
\hline & 0.122 & 0.123 & 0.112 & 0.112 \\
\hline \multicolumn{5}{|l|}{ Lead investor characteristics } \\
\hline \multirow[t]{2}{*}{$=1$ if lead investor in current round is entrant } & $0.283^{* * *}$ & $0.282^{* * *}$ & $0.262^{* * *}$ & $0.259^{* * *}$ \\
\hline & 0.027 & 0.027 & 0.027 & 0.027 \\
\hline \multirow[t]{2}{*}{ investment experience (log dollars under management) } & $0.076^{* * *}$ & $0.075^{* * *}$ & $0.069^{* * *}$ & $0.068^{* * *}$ \\
\hline & 0.004 & 0.004 & 0.004 & 0.004 \\
\hline \multicolumn{5}{|l|}{ Market, state, and industry characteristics } \\
\hline \multirow[t]{2}{*}{ value-weighted mean industry book/market ratio } & $-0.392^{* *}$ & $-0.349^{*}$ & $-0.550^{* * *}$ & $-0.432^{* *}$ \\
\hline & 0.141 & 0.141 & 0.146 & 0.146 \\
\hline \multirow[t]{2}{*}{ price index of publicly traded equity in same industry } & $0.286^{* * *}$ & $0.288^{* * *}$ & $0.308^{* * *}$ & $0.310^{* * *}$ \\
\hline & 0.025 & 0.025 & 0.026 & 0.026 \\
\hline \multirow[t]{2}{*}{ log inflow into VC funds in industry $(\$ \mathrm{~m})$} & $0.140^{* * *}$ & $0.142^{* * *}$ & $0.135^{* * *}$ & $0.136^{* * *}$ \\
\hline & 0.012 & 0.012 & 0.013 & 0.013 \\
\hline \multirow[t]{2}{*}{$\log$ no. deals in market } & 0.030 & 0.004 & 0.032 & 0.004 \\
\hline & 0.039 & 0.040 & 0.038 & 0.039 \\
\hline \multirow[t]{2}{*}{ proxy for omitted location-specific variable } & 9.048 & $3.197^{* *}$ & 4.417 & 1.299 \\
\hline & 4.894 & 1.134 & 4.335 & 0.924 \\
\hline \multirow[t]{2}{*}{ proxy for omitted industry-specific variable } & 1.909 & 0.554 & 7.310 & $3.911^{* * *}$ \\
\hline & 2.948 & 0.673 & 3.855 & 0.990 \\
\hline \multicolumn{5}{|l|}{ Company characteristics } \\
\hline \multirow[t]{2}{*}{$=1$ if seed or early-stage } & $-0.658^{* * *}$ & $-0.656^{* * *}$ & $-0.644^{* * *}$ & $-0.642^{* * *}$ \\
\hline & 0.023 & 0.023 & 0.026 & 0.026 \\
\hline \multirow[t]{2}{*}{$=1$ if second funding round } & $0.460^{* * *}$ & $0.460^{* * *}$ & $0.487^{* * *}$ & $0.488^{* * *}$ \\
\hline & 0.027 & 0.027 & 0.030 & 0.030 \\
\hline \multirow[t]{2}{*}{$=1$ if third funding round } & $0.800^{* * *}$ & $0.799^{* * *}$ & $0.848^{* * *}$ & $0.847^{* * *}$ \\
\hline & 0.031 & 0.031 & 0.035 & 0.035 \\
\hline \multirow[t]{2}{*}{$=1$ if fourth or later funding round } & $0.964^{* * *}$ & $0.963^{* * *}$ & $1.035^{* * *}$ & $1.034^{* * *}$ \\
\hline & 0.030 & 0.030 & 0.033 & 0.033 \\
\hline \multicolumn{5}{|l|}{ Diagnostics } \\
\hline Adjusted $R^{2}$ & $40.1 \%$ & $40.1 \%$ & $41.5 \%$ & $41.6 \%$ \\
\hline Wald test: all coeff. $=0(F)$ & $466.5^{* * *}$ & $467.2^{* * *}$ & $398.7^{* * *}$ & $400.4^{* * *}$ \\
\hline No. of rounds & 11,106 & 11,106 & 9,003 & 9,003 \\
\hline
\end{tabular}


Table X. Alternative Round-level Valuation Models.

The unit of observation is a funding round and the dependent variable is the log of the valuation put on the company in that round. To save space, we report only the coefficient estimates of interest; the coefficient estimates for the controls mirror those shown in Table IX. Panel A is the OLS-with-market-fixed-effects specification taken from Table IX and is included for ease of comparison. Panel B corrects for possible endogenous disclosure of round valuations by including the inverse Mill's ratio from an ordered probit following Hwang, Quigley, and Woodward (2005). Panel C is a mixed linear model with two levels of random effects: For the company and for the market. This hierarchical model, which assumes that company effects are nested within market effects, allows us to control for unobserved company-level valuation drivers. Panel D combines the selection correction of Panel B with the twolevel model of Panel C. Standard errors are shown in italics. We use ${ }^{* * *},{ }^{* *}$, and ${ }^{*}$ to denote significance at the $0.1 \%$, $1 \%$, and $5 \%$ level (two-sided), respectively.

\begin{tabular}{|c|c|c|c|c|}
\hline \multirow[b]{3}{*}{ Network measure used: } & \multicolumn{4}{|c|}{ Dependent variable: $\log$ valuation } \\
\hline & \multicolumn{2}{|c|}{ State markets } & \multicolumn{2}{|c|}{ MSA markets } \\
\hline & $\begin{array}{c}\text { asymmetric } \\
\text { density }\end{array}$ & $\begin{array}{c}\text { symmetric } \\
\text { density }\end{array}$ & $\begin{array}{l}\text { asymmetric } \\
\text { density }\end{array}$ & $\begin{array}{c}\text { symmetric } \\
\text { density }\end{array}$ \\
\hline \multicolumn{5}{|l|}{ Panel A: Market fixed effects model (from Table IX) } \\
\hline \multirow[t]{2}{*}{ network measure } & $-12.503^{* * *}$ & $-3.898^{* * *}$ & $-10.657^{* * *}$ & $-4.227^{* * *}$ \\
\hline & 2.361 & 0.685 & 2.135 & 0.682 \\
\hline \multirow[t]{2}{*}{ fraction of deals won by entrants in previous year } & $0.616^{* * *}$ & $0.648^{* * *}$ & $0.353^{* *}$ & $0.385^{* * *}$ \\
\hline & 0.122 & 0.123 & 0.112 & 0.112 \\
\hline \multirow[t]{2}{*}{$=1$ if lead investor in current round is entrant } & $0.283^{* * *}$ & $0.282^{* * *}$ & $0.262^{* * *}$ & $0.259^{* * *}$ \\
\hline & 0.027 & 0.027 & 0.027 & 0.027 \\
\hline \multicolumn{5}{|l|}{ Panel B: Heckman-selection corrected model } \\
\hline \multirow[t]{2}{*}{ network measure } & $-10.983^{* * *}$ & $-3.449^{* * *}$ & $-9.014^{* * *}$ & $-3.671^{* * *}$ \\
\hline & 2.377 & 0.690 & 2.151 & 0.688 \\
\hline \multirow[t]{2}{*}{ fraction of deals won by entrants in previous year } & $0.631^{* * *}$ & $0.659^{* * *}$ & $0.380^{* * *}$ & $0.408^{* * *}$ \\
\hline & 0.122 & 0.122 & 0.112 & 0.112 \\
\hline \multirow[t]{2}{*}{$=1$ if lead investor in current round is entrant } & $0.292^{* * *}$ & $0.291^{* * *}$ & $0.271^{* * *}$ & $0.269^{* * *}$ \\
\hline & 0.027 & 0.027 & 0.027 & 0.027 \\
\hline \multirow[t]{2}{*}{ inverse Mill's ratio } & $0.118^{* * *}$ & $0.115^{* * *}$ & $0.146^{* * *}$ & $0.140^{* * *}$ \\
\hline & 0.021 & 0.023 & 0.025 & 0.026 \\
\hline \multicolumn{5}{|l|}{ Panel C: Two-level mixed effects model } \\
\hline \multirow[t]{2}{*}{ network measure } & $-9.094^{* * *}$ & $-2.721^{* * *}$ & $-9.934^{* * *}$ & $-3.521^{* * *}$ \\
\hline & 2.116 & 0.610 & 1.929 & 0.612 \\
\hline \multirow[t]{2}{*}{ fraction of deals won by entrants in previous year } & $0.478^{* * *}$ & $0.492^{* * *}$ & $0.347^{* * *}$ & $0.364^{* * *}$ \\
\hline & 0.104 & 0.104 & 0.096 & 0.096 \\
\hline \multirow[t]{2}{*}{$=1$ if lead investor in current round is entrant } & $0.221^{* * *}$ & $0.220^{* * *}$ & $0.211^{* * *}$ & $0.210^{* * *}$ \\
\hline & 0.024 & 0.024 & 0.024 & 0.024 \\
\hline LR test vs. linear model $\left(\chi^{2}\right)$ & $2,391.0^{* * *}$ & $2,425.6^{* * *}$ & $1,979.6^{* * *}$ & $1,977.0^{* * *}$ \\
\hline \multicolumn{5}{|l|}{ Panel D: Heckman-correct mixed effects model } \\
\hline \multirow[t]{2}{*}{ network measure } & $-7.245^{* * *}$ & $-2.165^{* * *}$ & $-8.127^{* * *}$ & $-2.902^{* * *}$ \\
\hline & 2.135 & 0.617 & 1.944 & 0.619 \\
\hline \multirow[t]{2}{*}{ fraction of deals won by entrants in previous year } & $0.487^{* * *}$ & $0.499^{* * *}$ & $0.373^{* * *}$ & $0.388^{* * *}$ \\
\hline & 0.104 & 0.104 & 0.096 & 0.096 \\
\hline \multirow[t]{2}{*}{$=1$ if lead investor in current round is entrant } & $0.229^{* * *}$ & $0.227^{* * *}$ & $0.219^{* * *}$ & $0.219^{* * *}$ \\
\hline & 0.024 & $0.024_{* * *}$ & 0.024 & 0.024 \\
\hline \multirow[t]{2}{*}{ inverse Mill's ratio } & $0.127^{* * *}$ & $0.124^{* * *}$ & $0.152^{* * *}$ & $0.149^{* * *}$ \\
\hline & 0.021 & 0.021 & 0.023 & 0.023 \\
\hline LR test vs. linear model $\left(\chi^{2}\right)$ & $2,424.8^{* * *}$ & $2,456.5^{* * *}$ & $2,019.1^{* * *}$ & $2,013.0^{* * *}$ \\
\hline
\end{tabular}

